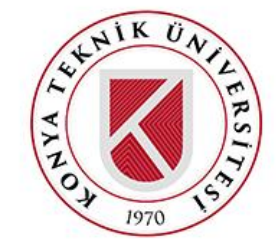

Konya Mühendislik Bilimleri Dergisi, c. 9, s. 3, 809-835, 2021

Konya Journal of Engineering Sciences, v. 9, n. 3, 809-835, 2021

ISSN: 2667-8055 (Elektronik)

DOI: $10.36306 /$ konjes.907309

\title{
AN ECONOMIC AND TECHNICAL REVIEW FOR THE UTILIZATION OF HVDC IN TURKEY AND IN THE WORLD
}

\author{
${ }^{1}$ Hakan ACAROĞLU (D) , ${ }^{2}$ Atabak NAJAFI ${ }^{(D)}$, 3Ömer KARA (D) , ${ }^{3}$ Burcu YÜRÜK (D) \\ 1,3 Eskisehir Osmangazi University, Economics and Administrative Sciences Faculty, Economics Department, \\ Eskisehir, TURKEY \\ ${ }^{2}$ Eskisehir Osmangazi University, Engineering and Architecture Faculty, Electrical and Electronics Engineering \\ Department, Eskisehir, TURKEY \\ ${ }^{4}$ Usak University, Accounting and Finance Management Department, Usak, TURKEY \\ 1hacaroglu@ogu.edu.tr, 2ataberknajafi@ogu.edu.tr, 3okara@ogu.edu.tr, ${ }^{3}$ burcu.yuruk@usak.edu.tr
}

(Geliş/Received: 31.03.2021; Kabul/Accepted in Revised Form: 15.06.2021)

\begin{abstract}
In recent years, it is seen that High Voltage Direct Current (HVDC) transmission line systems have come to the fore in the field of energy efficiency in the world. Therefore, it is predicted that analyzing the technological and economic advantages of HVDC transmission line systems will make an important contribution to energy efficiency policies. In this regard, this study aims to examine the technological and economic advantages of HVDC transmission systems through the historical development with applications in Turkey and in the world. In addition to this, it is expected that the evaluation of the effects of energy efficiency on the economy will bring a different perspective to the energy and economic literature. Therefore, it is thought that energy and economic policies for the spread of HVDC transmission line systems worldwide will be essential. The asymmetric distribution of natural energy sources in the world causes energy supply security problems in the countries such as Turkey in terms of high foreign dependence on energy. For this reason, it is necessary to meet the increasing energy demand and increase the existing capacity day by day. Besides, it is important to develop policies for efficient use of energy. HVDC technology is extremely important for a developing country like Turkey. Moreover, it is known that this energy transmission technology has become widespread in developed countries. Thereby, a technical comparison is done for investment costs of the transmission system in Germany. As a result, other than bringing economic benefits with the energy transmission of Turkey through HVDC, it has important potential for making energy transmission possible with her neighbors and European Union countries.
\end{abstract}

Key Words: High voltage direct current, Transmission line system, Energy, Turkey

\section{Yüksek Gerilim Doğru Akım (YGDA) İletim Hatlarının Türkiye ve Dünyada Kullanımına İlişkin Ekonomik ve Teknik Bir İnceleme}

ÖZ: Son yıllarda dünyada enerji verimliliği alanında Yüksek Gerilim Doğru Akım (YGDA) iletim hattı sistemlerinin ön plana çıktığı görülmektedir. Bu nedenle, YGDA iletim hattı sistemlerinin teknolojik ve ekonomik üstünlüklerinin analiz edilmesinin enerji verimliliği politikalarına önemli bir katkı sağlayacağ öngörülmektedir. Bu bağlamda bu çalışma, YGDA iletim hattı sistemlerinin, Türkiye'de ve dünyada tarihsel gelişimi ile uygulama örnekleri üzerinden teknolojik ve ekonomik avantajlarının incelenmesini amaçlamaktadır. Buna ek olarak, çalışmada enerji verimliliğinin ekonomi üzerindeki etkilerinin değerlendirilmesinin, enerji ve ekonomi literatürüne farklı bir bakış açısı getireceği beklenmektedir. Böylece, YGDA iletim hattı sistemlerinin dünya genelinde yaygınlaşmasına yönelik enerji ve ekonomi 
politikalarının önem kazanacağı düşünülmektedir. Dünyada doğal enerji kaynaklarının asimetrik dağılımı, Türkiye gibi enerjide dışa bağımlılığı yüksek olan ülkeler açısından enerji arz güvenliği sorununa neden olmaktadır. Bu sebeple her geçen gün artan enerji talebinin karşılanması ve mevcut kapasitenin artırılması gerekmektedir. Ayrıca, enerjinin verimli kullanılmasına yönelik politikaların geliştirilmesi de önem taşımaktadır. YGDA teknolojisi Türkiye gibi gelişmekte olan bir ülke için son derece önemlidir. Ayrıca gelişmiş ülkelerde bu enerji iletim teknolojisinin yaygınlaştığı bilinmektedir. Bu nedenle, Almanya' daki bir iletim sisteminin yatırım maliyetleri için teknik bir karşılaştırma yapılmıştır. Sonuç olarak, Türkiye'nin enerji iletimini YGDA ile sağlaması ekonomik getirilerinin yanı sıra, komşu ve Avrupa Birliği ülkeleriyle enerji iletimini mümkün kılması açısından ekonomik bir potansiyel de taşımaktadır.

Anahtar Kelimeler: Yüksek gerilim doğru akım, İletim hattı sistemi, Enerji, Türkiye.

\section{INTRODUCTION}

Demand for electrical energy, which is an important production input alongside labor and capital, continues to increase worldwide day by day. Especially in developing countries including Turkey, foreign dependence on energy leads to an increase in the current deficit by playing an import increasing role in meeting the growing demand. This situation affecting the economy reveals the necessity of countries to handle their energy policies with economic policies. In recent years, it is observed that the policies of countries to reduce foreign dependency and increase their existing production capacity have accelerated for each country in order to meet the increasing demand. In this context, not only the capacity increase but also ensuring the efficiency of existing capacity contributes to the rapid development of transmission line technologies. When the historical process is analyzed, it is seen that the electrical energy transmission and distribution, which is used extensively, is realized as alternating current (AC) and direct current (DC). The network development in different periods varies in terms of voltage class, network size, generator unit capacity, and technical and economic aspects due to the developments in transmission technologies over time. Based on these aspects, the history of the network development can be separated into different phases. From the end of nineteenth century to the midst of the twentieth century, the electrical network became prominent with the usage of AC in production and transmission as well as its distribution. It was the first phase that ceased with the end of the World War II. During this phase, the generator unit capacity was less than $200 \mathrm{MW}$; AC transmission was prevailing only up to $220 \mathrm{kV}$ (Liu, 2014).

Higher voltage transmission systems that are needed in this period and become widespread over time can be classified as high voltage (HV-35-220kV), extra-high voltage (EHV-330-1000kV), and ultrahigh voltage (UHV-1000kV and more) (Long and Nilsson, 2007). The implementation of electricity transmission, which is used extensively today, with the least cost and transmission loss is of great importance in terms of ensuring energy efficiency and positive effects on the national economies.

It is observed that the use of HVDC transmission line systems has become widespread with its technological and economic advantages, and parallel to this, studies on HVDC transmission line systems have also become widespread. When these studies are examined, it is seen that studies especially on technical aspects such as the integration of HVDC transmission lines into existing AC networks (Brask, 2008; Burger and Tuson, 2005), effects on network reliability and development (Kotb, 2018; Stenberg, 2013), functionality of HVDC converter at world stations (Almgren et al., 1998; Beerten et al., 2014), reliability of test systems (Bertling and Pramod, 2011), VSC (voltage source converter)-HVDC modeling (Träff and Lennerhag, 2013), location determination for in-network application (Shuai, 2012) and applicability at distribution level (Giraneza, 2013) become prominent. In a limited number of studies evaluating the market structure, geographical distribution, and technical/economic superiority of HVDC transmission line systems, it is seen that the subject has been examined within the scope of engineering science (Alassi et al,, 2019; Gamit et al., 2015; Rudervall et al., 2000). It is seen that the studies focused on the details of HVDC transmission line systems are generally focused on their applications in China (Mircea and Philip, 2017; Cao and Cai, 2013; Pudney, 2012). 
In this interdisciplinary study, the technological and economic advantages of HVDC transmission line systems are evaluated within the scope of engineering and economics. Thereby, a technical comparison is shown for investment costs of the transmission system in a developed country: Germany. Finally, other than bringing economic benefits with the energy transmission of Turkey through HVDC, it has important potential for making energy transmission possible with Turkey's neighbors and European Union countries. It is thought that this study will give a different perspective to the literature especially with its evaluations regarding the energy efficiency of HVDC transmission line systems and its role in reducing foreign dependence on energy in the future. In addition, it is anticipated that this study will contribute to the joint evaluation of energy and economic policies to be developed for the applicability of HVDC transmission line technologies in countries with high foreign dependence on energy, especially in Turkey.

\section{HIGH VOLTAGE CLASSES: ADVANTAGES VERSUS DISADVANTAGES}

Historically, when examining high voltage classes, HVAC has been the major transmission technology that benefited from the initial advancement of AC transformers. It is because AC allows the HVAC transmission for longer distances and lower losses, as well as "Current Wars" resulting in favor of Tesla. Nonetheless, with the development of mercury arc valves and their prevailing adoption in the 1930s and HVDC allowing energy to be transmitted at higher voltages, DC has entered the transmission market again (Alassi et al., 2019). The advantages versus disadvantages of HVDC can be found as follows:

HVDC Advantages:

- Lowering line cost as HVDC transmission requires fewer conductors; for example, two conductors are used for a typical bipolar HVDC line compared to three-phase HVAC.

- HVDC transmission lines cause reduction of Corona losses compared to HVAC of similar power.

- As HVDC can carry more power per conductor of given size, there is a reduction of the wiring and strut profile for a given power transmission capacity.

- HVDC uses power electronic systems in transmission lines. Since these devices have no mechanical moving parts, there is less probability of failure, so have very robust performance and long life under the nominal conditions.

- It is an undeniable fact that the least harmful transmission to the environment is DC transmission.

- Less losses on DC lines makes DC transmission a more efficient system.

- With the HVDC system, the power flow can be controlled quickly and precisely both the power level and the direction. HVDC Disadvantages:

- HVDC transmission lines are expensive because they are needed in rectifier and inverter circuits. In addition, since power electronics elements are used, it will cause harmonic increase on the line. A suitable filter needs to be designed to solve this problem.

- Disconnection of direct current in HVDC transmission lines is more difficult.

- Since power electronics circuits are used, control systems are complex and require expertise.

- It can be set up between two points. No addition can be made to the desired point of the line.

\section{HVDC TRANSMISSION LINES}

\subsection{The Development of HVDC Transmission Lines in History}

HVDC transmission lines are generally less costly than HVAC for transmission distances of more than $600 \mathrm{~km}$ (and power above 1000MW) (Figueroa-Acevedo et al., 2015). In cases where the HVDC power transmission is up to $600-800 \mathrm{M}$, approximately $300 \mathrm{~km}$ distances have been reached. Underwater cables and cable lengths up to approximately $1000 \mathrm{~km}$ are in the planning phase. As mentioned earlier, HVDC power transmission technology over long distances was introduced in the second half of the last century. From initial installations that allow less than 100MW of power transmission, the transmission capacity is 
constantly increasing towards higher values (Mazzanti and Marzinotto, 2013). In order to overcome the technical limitations on reactive power demand of HVAC cables for long distances, the first commercial applications of HVDC transmission are produced, especially in underwater transmission. Later, HVDC has been applied for long-distance air lines and it has been found that it offers cost-effective solutions compared to HVAC technology as the transmission distance increases. Moreover, it is seen that the lower cost structure of HVDC compared to HVAC has played an important role in the development of HVDC transmission lines over time.

When important projects in the first period developments of HVDC are examined, it is seen that a $115 \mathrm{~km}$ long underground cable system, providing $60 \mathrm{MW}$ power with $200 \mathrm{kV}$ voltage value and $150 \mathrm{~A}$ cable amp, to Berlin, Germany was ready to be energized in 1945 but it was never employed due to the events related to World War II. In 1952, a transmission line of $110 \mathrm{kV}$ was constructed in China by her own technologies (Tiku, 2014). In 1954, 220 kV Fengman-Lishizhai line was constructed. In 1956, the Kuybyshev-Moscow transmission line became operational in the Soviet Union, making it the world's first application of $500 \mathrm{kV}$ in transmission (Ukil, 2015). In 1965, the World's first $735 \mathrm{kV}$ transmission line, between Quebec City and Montreal, was completed. A $750 \mathrm{kV}$ pilot transmission line in the Soviet Union and a $765 \mathrm{kV}$ transmission line in the United States were constructed in 1967 and 1969 respectively.

It is observed that the power capacity and transmission line lengths have increased with the developments in the first period of HVDC as it is happening today. For instance, Sardinia Peninsula Italy (SAPEI) HVDC interconnection is a bipolar system used for 1000MW transmission over $440 \mathrm{M}$ cable length, which is known as the longest project in the world as of today. It connects Fiumesanto, which is $1650 \mathrm{~m}$ below sea level in the Tyrrhenian Sea, to Sabotino (Mazzanti and Marzinotto, 2013).

\subsubsection{Development of HVDC Transmission Lines in the World}

When the geographical distribution of HVDC transmission systems in the world is examined, it is seen that the Asian continent takes the first place. Many HVDC projects, especially in this continent where China and India are located, have been built in order to provide efficiency in the transmission of energy to long distances because of the geographical width of those countries. Especially in China, it is seen that the current connections exceed $10000 \mathrm{MW}$. It is seen that Asia has the largest average transmission voltage since most of the HVDC connections established after 2010 have been $\pm 800 \mathrm{kV}$, which has increased recently. The European continent follows the Asian continent in the configuration of the HVDC projects. However, considering the demand and geographical differences of HVDC connections in Europe, it is seen that higher power and longer distances are not required compared to the Asian continent and 1.1 GW cross-border connections are dominant (L'Abbate et al., 2015). Asia and Europe are followed by North America with 1.5 GW capacity, South America with 1.4 GW capacity and other regions with $1.0 \mathrm{GW}$ capacity, in order (Alassi et al., 2019). When the geographical distribution of the maximum voltage reached in HVDC transmission line systems is examined, the continent of Asia with the highest voltage transmission $(1100 \mathrm{kV})$ is followed by the continent of South America with $800 \mathrm{kV}$, the continents of Europe and North America with $600 \mathrm{kV}$, and other continents with $500 \mathrm{kV}$, in order (Liu et al., 2018). When the market of HVDC transmission line systems in the world is analyzed, ABB, which has been providing service for 60 years, dominates more than half the market. Along with ABB, Siemens and Alstom Grid (General Electric since 2015) has emerged as other important service providers in the HVDC transmission line systems market. Some projects with HVDC transmission line systems in the world are summarized in Table 1 (IEEE, 2006). 
Table 1. Summary of HVDC transmission line projects in the world (1954-2019).

\begin{tabular}{|c|c|c|c|c|c|c|}
\hline Project & $\begin{array}{ll}\text { HVDC } & \text { Service } \\
\text { Provider } & \\
\end{array}$ & Year & $\begin{array}{l}\text { Power } \\
(\mathrm{MW})\end{array}$ & $\begin{array}{l}\text { DC Voltage } \\
(\mathrm{kV})\end{array}$ & $\begin{array}{l}\text { Line/Cable } \\
(\mathrm{km})\end{array}$ & Country \\
\hline GOTLAND I & ASEA & 1954 & 20 & \pm 100 & 96 & Sweden \\
\hline SQUARE BUTTE & GENERAL ELECTRIC & 1977 & 500 & \pm 250 & 749 & USA \\
\hline NELSON RIVER 2 & AEG/BBC/SIEMENS & 1978 & 900 & \pm 250 & 940 & Canada \\
\hline GOTLAND II & ASEA & 1983 & 130 & 150 & 100 & Sweden \\
\hline NELSON RIVER 2 & AEG/BBC/SIEMENS & 1985 & 2000 & \pm 500 & 940 & Canada \\
\hline GOTLAND III & ASEA & 1987 & 260 & \pm 150 & 103 & Sweden \\
\hline $\begin{array}{l}\text { GESHA (GEZHOUBA- } \\
\text { SHANGHAI) }\end{array}$ & ABB/SIEMENS & 1990 & 1200 & \pm 500 & 1046 & China \\
\hline RIHAND-DELHI & ABB/BHEL & 1991 & 750 & 500 & 814 & India \\
\hline RIHAND-DELHI & ABB/BHEL & 1992 & 1500 & \pm 500 & 814 & India \\
\hline SKAGERRAK III & $\mathrm{ABB}$ & 1993 & 500 & \pm 350 & 240 & $\begin{array}{l}\text { Norway- } \\
\text { Denmark }\end{array}$ \\
\hline BALTIC CABLE & $\mathrm{ABB}$ & 1994 & 600 & \pm 450 & 261 & $\begin{array}{l}\text { Sweden- } \\
\text { Germany }\end{array}$ \\
\hline KONTEK & ABB/NKT CABLES & 1995 & 600 & 400 & 171 & $\begin{array}{l}\text { Denmark- } \\
\text { Germany }\end{array}$ \\
\hline CHANDRAPUR-PADGHE & $\mathrm{ABB}$ & 1998 & 1500 & \pm 500 & 736 & India \\
\hline GOTLAND HVDC LIGHT & $\mathrm{ABB}$ & 1999 & 50 & \pm 60 & 70 & Sweden \\
\hline SWEPOL LINK & ABB & 2000 & 600 & \pm 450 & 254 & $\begin{array}{l}\text { Sweden- } \\
\text { Poland }\end{array}$ \\
\hline DIRECTLINK & $\mathrm{ABB}$ & 2000 & $3 \times 60$ & \pm 80 & 59 & Australia \\
\hline GRITA & PIRELLI/ABB & 2001 & 500 & 400 & 316 & $\begin{array}{l}\text { Greece- } \\
\text { Italy }\end{array}$ \\
\hline TIAN-GUANG & SIEMENS & 2001 & 1800 & \pm 500 & 960 & China \\
\hline NELSON RIVER 1 & SIEMENS & 2001 & 1854 & \pm 463 & 890 & Canada \\
\hline CROSS SOUND & $\mathrm{ABB}$ & 2002 & 330 & \pm 150 & 40 & USA \\
\hline MURRAYLINK & ABB & 2002 & 200 & \pm 150 & 176 & Australia \\
\hline EAST-SOUTH & SIEMENS & 2003 & 2000 & \pm 500 & 1400 & India \\
\hline \multicolumn{7}{|l|}{ INTERCONNECTOR } \\
\hline THREE GORGES-CHANGZHOU & ABB/SIEMENS & 2003 & 3000 & \pm 500 & 860 & China \\
\hline THREE GORGES-GUANGDONG & $\mathrm{ABB}$ & 2004 & 3000 & \pm 500 & 940 & China \\
\hline GUI-GUANG & SIEMENS & 2004 & 3000 & \pm 500 & 936 & China \\
\hline BASSLINK & SIEMENS & 2006 & 500 & 400 & 360 & Australia \\
\hline GUIZHOU-GUANGDONG 2 & SIEMENS & 2008 & 3000 & \pm 500 & 1225 & China \\
\hline TRANS BAY & SIEMENS & 2010 & 400 & \pm 200 & 88 & USA \\
\hline XIANGJIABA-ŞANGAY & $\mathrm{ABB}$ & 2010 & 6400 & \pm 800 & 2000 & China \\
\hline SAPEI & $\mathrm{ABB}$ & 2011 & 1000 & 500 & 435 & Italy \\
\hline $\begin{array}{l}\text { BLACK SEA TRANSMISSION } \\
\text { NETWORK }\end{array}$ & SIEMENS & 2013 & $2 \times 350$ & 96 & 283 & $\begin{array}{l}\text { Georgia- } \\
\text { Turkey }\end{array}$ \\
\hline INELFE & SIEMENS & 2015 & $2 \times 1000$ & \pm 320 & 64 & $\begin{array}{l}\text { France- } \\
\text { Spain }\end{array}$ \\
\hline DOLWIN1 & $\mathrm{ABB}$ & 2015 & 800 & \pm 320 & 165 & Germany \\
\hline WESTERN YGDA LINK & SIEMENS & 2016 & 2200 & \pm 600 & 422 & England \\
\hline MARITIME LINK & $\mathrm{ABB}$ & 2017 & 500 & 200 & 360 & Canada \\
\hline CAITHNESS MORAY YGDA LINK & ABB & 2018 & 1200 & \pm 320 & 160 & Scotland \\
\hline BORWIN3 & SIEMENS & 2019 & 900 & \pm 320 & 200 & Germany \\
\hline
\end{tabular}

Source: (IEEE, 2006).

It is known that the increasing prevalence of HVDC transmission line systems in the world is due to their technical, economical and environmentally superior features compared to HVAC. Considering the past, present and future of HVDC, it is predicted that its technological, economic and environmental superiorities will come to the fore respectively (Figure 1) (Long and Nilsson, 2007). 


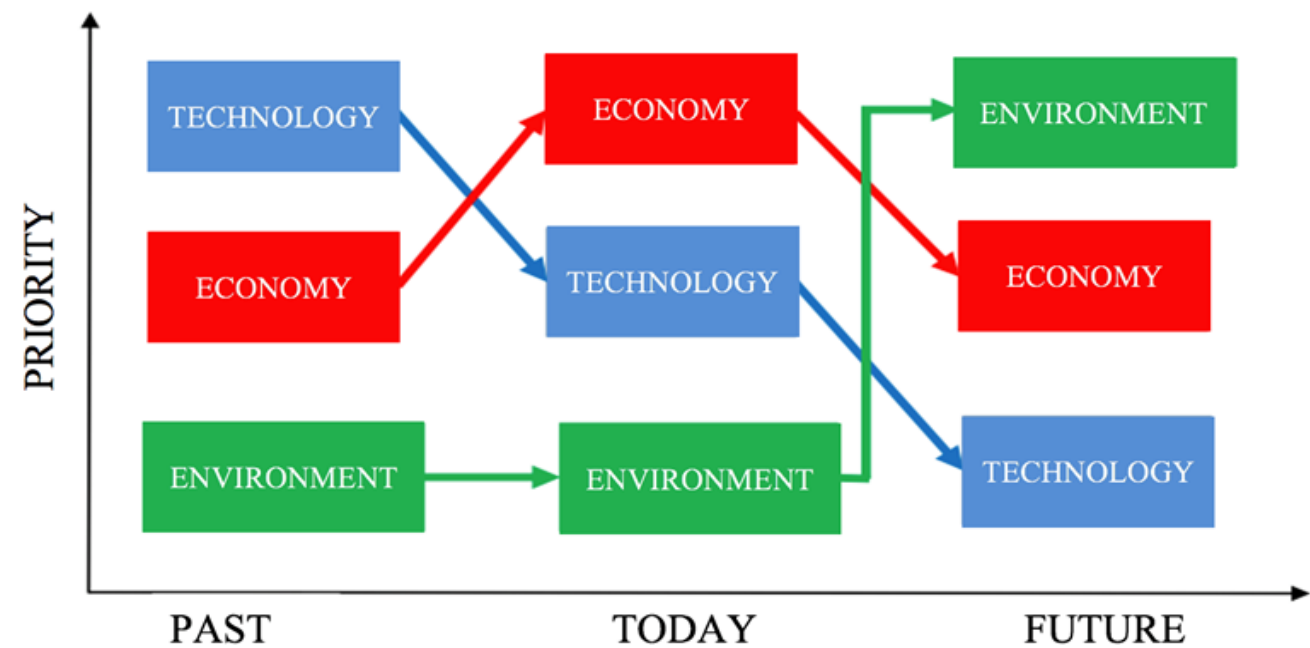

Figure 1. Vision of HVDC transmission line systems (Long and Nilsson, 2007).

Considering the area covered by the transmission lines, the area cost of the HVDC line is not as high as that of an AC line. This also reduces the visual impact. In HVDC systems, environmental issues such as visual impact, audible sound, electromagnetic compatibility, and the use of ground or sea return path in mono-polar application are important for converter stations. It can be said that the HVDC system is highly compatible with any environment and can now be integrated into the system without causing any environmentally important issues (Bahrman, 2006).

\subsubsection{The Development of HVDC Transmission Lines in Turkey}

To meet the constantly growing demand for electricity in Turkey, the development of transmission lines with technical economic and environmental advantages should accelerate. In this context, the connection of Turkey's electricity system to (ENTSO-E CESA) system, which is started in 2005, in a synchronous parallel way was carried out as of April 15, 2015. With this treaty, steps have been taken to realize synchronal connection structures with neighboring countries other than our western neighbors. In 2016, ENTSO-E CESA observer membership agreement is signed and Turkey became the first and only observer. 2019 is the last year for observer membership and negotiations are still ongoing. Since it is predicted that neighboring countries such as Georgia, Iran, Iraq and Syria will not be able to meet ENTSOE standards in the near future, the applicability of HVDC transmission line systems with these countries seems possible to the extent permitted by ENTSO-E standards. The existing interconnection lines in Turkey as of 2018 is located in Figure 2 (TEİAŞ, 2016).

According to TEİAS data, electricity is imported by the isolated region method from Iran. The efforts to transform this transfer to asynchronous connection with back-to-back connected HVDC system started gradually (from 500-600MW to 1000-1200MW) as of 2016. The fact that HVDC systems allow asynchronous structure is important in terms of facilitating the exchange of power and enabling the expansion of the electricity trade volume between countries. In this context, for our country, Georgia started to use the back-to-back connected HVDC system in Ahiska and enabled the transfer of electricity into an asynchronous parallel connection. It is seen that they accelerate their work for new connections. Apart from these developments, the interconnected project of our country with 8 countries (Egypt, Jordan, Lebanon, Libya, Iraq, Palestine and Syria) continues (TEİAŞ, 2018). 


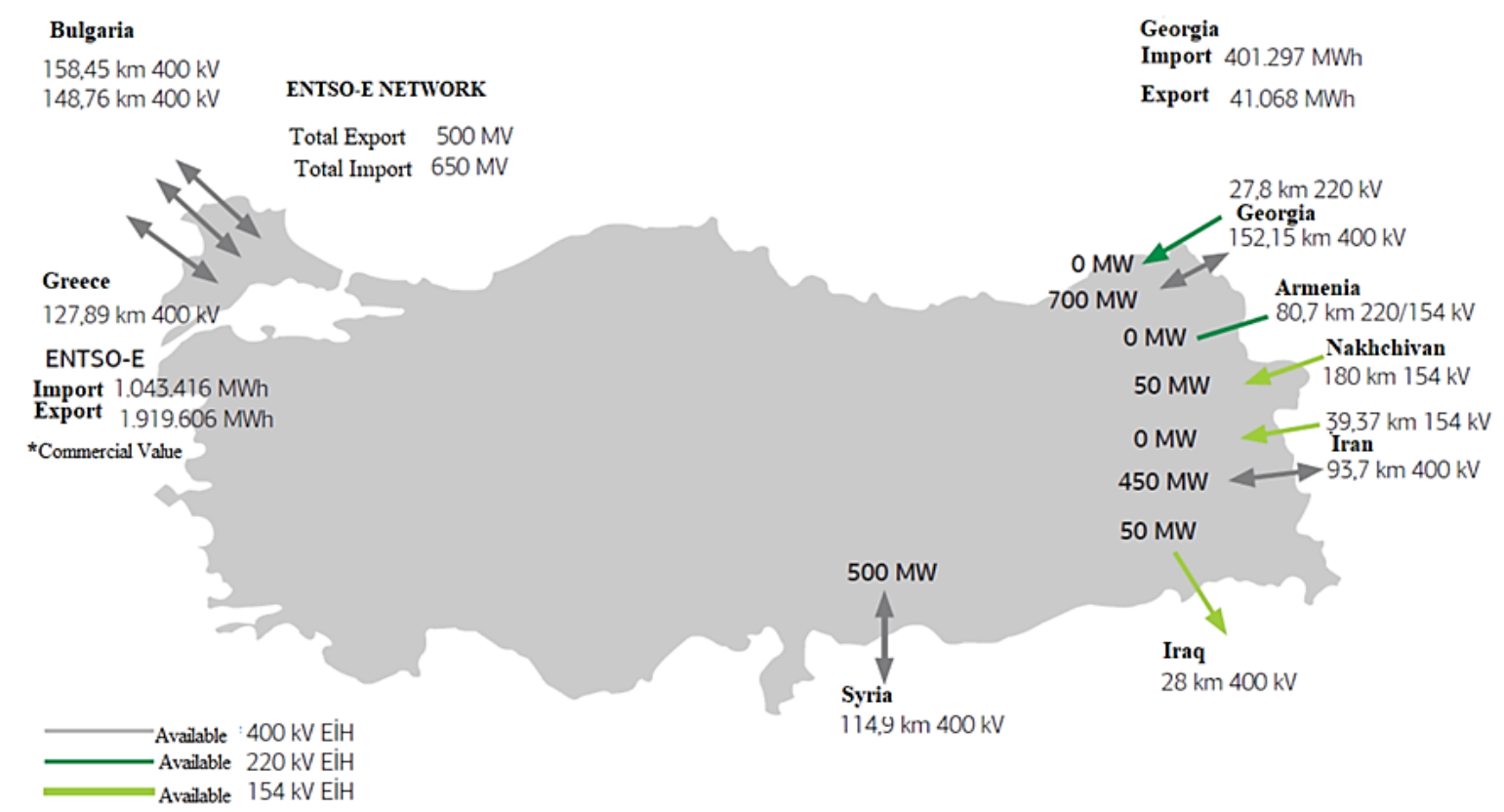

Figure 2. Interconnected lines, transportation capacity, and import-export values in Turkey (TEIAŞ, 2016).

It is thought that the HVDC connections to be established with the countries especially in Figure 2 will contribute to the economy of the country by reducing the transmission losses and minimizing the costs at the long distance. The first of the two-national level HVDC projects on the agenda is the electric power transmission line from Akkuyu Nuclear Power Plant and the other is an HVDC transmission line planned for Cyprus. A possible Akkuyu-Istanbul HVDC transmission line will consist of 4 units each with $1200 \mathrm{MW}$ power and it is expected to have 4800MW power. It is seen that HVDC systems are the most efficient solution for transmitting to Istanbul, where demand is high. Here, thyristor based HVDC systems or IGBT based HVDC systems are applicable. However, the technologies used here need to be analyzed well.

Before installing the HVDC system in Turkey, it is necessary to create a road map that identifies the possible future establishment of other HVDC system. Thus, the first project to be established needs to be developed accordingly. Otherwise, integration of HVDC stations to be installed, later will be a problem. When these scenarios are considered, a master plan covering all of them should be made. In line with the plan to be created, projects should be developed step by step. It is predicted that an HVDC transmission line between Istanbul and Akkuyu can form the backbone of such a scenario. It is thought that if every HVDC station to be installed in the future creates a DC network integrated to its installed stations, this will both increase the stability of the network and enable the use of energy resources more efficiently.

\subsection{HVDC Transmission Line Configuration}

The HVDC transmission system configuration, which is more advantageous than HVAC in terms of cost and transmission losses, has various components. These components can be listed as follows (Haugland, 2008):

- Converter station

- AC-DC filters

- Smoothing Reactors

- Reactive Power Source

- Reactor Inverter 


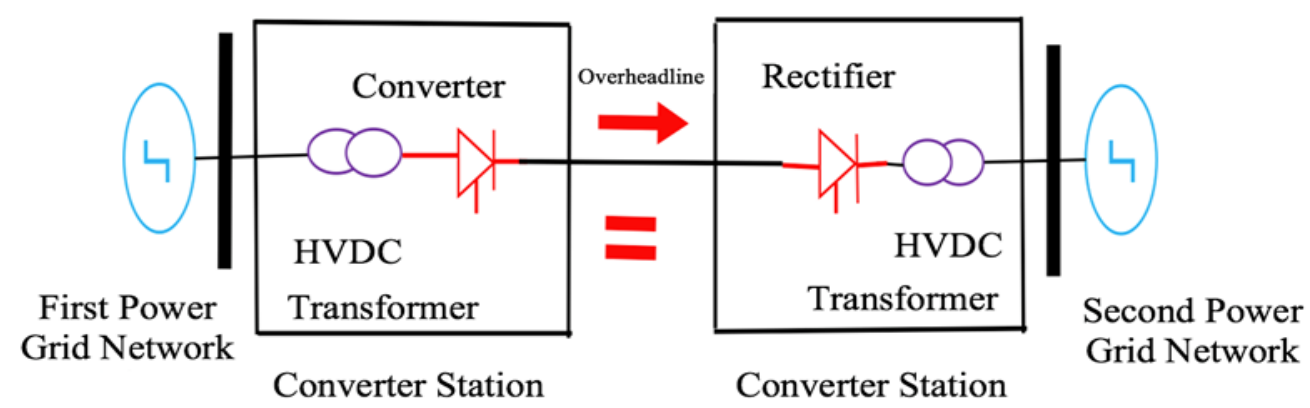

Figure 3. The configuration of the HVDC transmission line (Haugland, 2008).

Direct current configuration can be generally classified as mono-polar, bi-polar and homo-polar system as shown in Figure 4 (Haugland, 2008). In the mono-polar DC systems only one conductor (positive or negative end) is used. This configuration is often used as the first step of the DC link until the load requires upgrading to the bipolar link. Konti-Skan (1965) and Sardinia-Italy (1967) projects are examples of single circuit links. In bipolar DC current systems, which are known as the most common configuration type, two conductors (positive and negative) are used with the same voltage (Zangana and Erçelebi, 2016; Yidong and $\mathrm{Yu}, 2013)$. There are sets of equal level converters in series link that increase the power transmission capacity on the DC side of each terminal. The grounded link between the converters is at one or both ends. Under the standard operation condition, the currents are the same in both poles and there is no ground current (Sood, 2004; Brenna et al., 2016).

Apart from the mono-polar and bipolar system in DC configuration; homo-polar, back-to-back, and multi-terminal system configurations are also included. In the homo-polar configuration, two conductors with the same end (usually negative) can be operated with a ground or metallic return (Sood, 2004). Besides, the back-to-back configuration, is often used to connect the asynchronous AC system. Inverter stations are located in the same place and no transmission line or cable is required. ArgentinaBrazil interconnection is an example of such system configuration. HVDC converter stations in a multiterminal configuration, are geographically separated by cables and transmission lines (Cotts, 2017). In this configuration, converter stations are connected to the same voltage or more converter stations are connected parallel in terms of one or both two poles in series. Sardinia-Corsica-Italy (SACOI) Pacific Intertie and Hydro Quebec links in USA are examples for the multi-terminal HVDC systems applications (Hausler, 1999; Kamalapur et al., 2014). HVDC transmission line link systems have advantages and disadvantages against each other. The advantages and disadvantages of the link systems are summarized as follows in Table 2. 


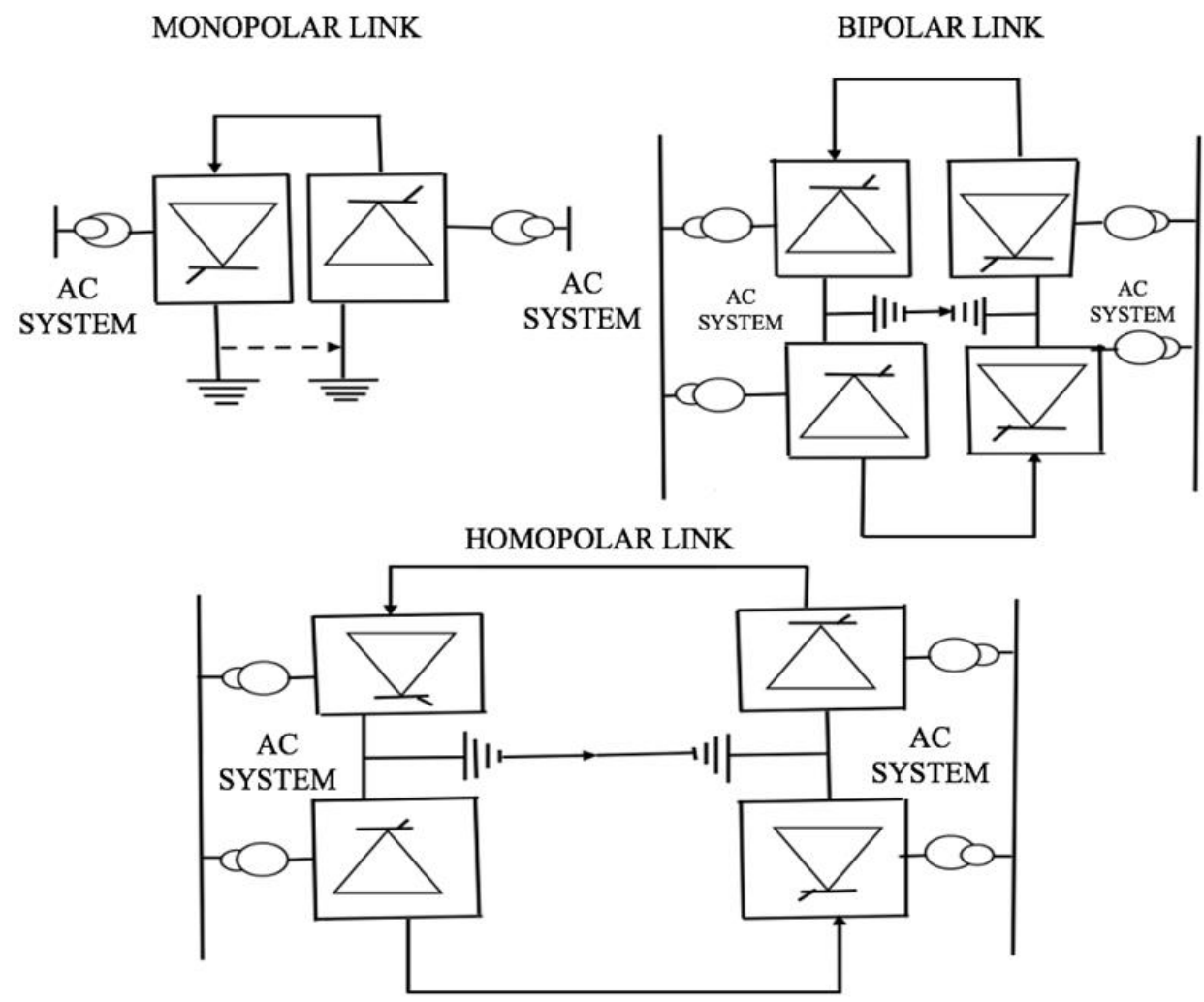

Figure 4. Different configurations for HVDC transmission lines (Haugland, 2008).

Table 2. HVDC Advantages and disadvantages.

\begin{tabular}{|c|c|c|}
\hline & Advantages & Disadvantages \\
\hline $\begin{array}{l}\text { Monopolar } \\
\text { System }\end{array}$ & $\begin{array}{l}\text { - The corona effect is less. } \\
\text { - Less conductor materials are } \\
\text { required for using the ground as a } \\
\text { return path. } \\
\text { - Less insulation is required. }\end{array}$ & \\
\hline Bipolar System & $\begin{array}{l}\text { - The power transition power } \\
\text { transition capacity is twice as the } \\
\text { mono-polar systems. } \\
\text { - When a fault is occurred in one } \\
\text { conductor, the half power } \\
\text { continues from the other } \\
\text { conductor. }\end{array}$ & $\begin{array}{l}\text { - The terminal equipment costs are } \\
\text { high. } \\
\text { - More conductor materials are } \\
\text { required. } \\
\text { - The corona effect is much higher. }\end{array}$ \\
\hline $\begin{array}{l}\text { Homo-polar } \\
\text { System }\end{array}$ & $\begin{array}{l}\text { The corona effect is less for the } \\
\text { reason of negative polar } \\
\text { conductors. } \\
\text { - More less conductor materials are } \\
\text { required for using the ground as a } \\
\text { return path. } \\
\text { - Failures caused by malfunction can } \\
\text { be prevented as transmission can } \\
\text { be provided from other conductors. } \\
\text { - High reliability. } \\
\text { - Less investment costs. }\end{array}$ & $\begin{array}{l}\text { - The ground return path causes } \\
\text { metallic wear. } \\
\text { - It causes noise in the underground } \\
\text { communication cables. }\end{array}$ \\
\hline
\end{tabular}

Source: (Haugland, 2008). 


\subsubsection{Converters}

The HVDC System converts the electrical current from AC to DC at the transmission end and DC to $\mathrm{AC}$ at the receiving end. The important component of this system is electronic converters, which can be classified into two main types of Line-Commutated (LCC) and voltage source converter (VSC). Possible circuits for the HVDC converters and comparison between LCC and VSC can be found in Figure 5 and Table 3.

LCC (line commutate converter) and VSC (voltage sourced converter) HVDC:

The figures below show the LCC (current sourced Line-commutated) and VSC (Voltage sourced self-commutated) circuits used in HVDC transmission lines.
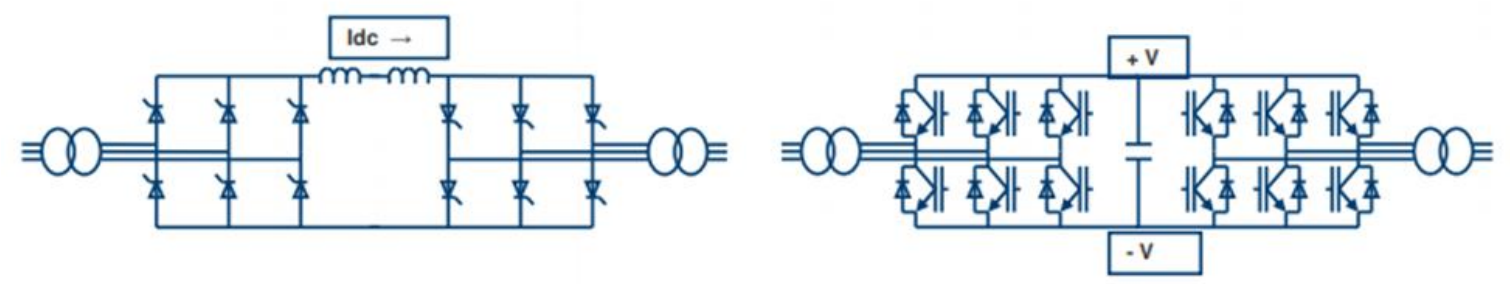

Figure 5: a) LCC circuit b) VSC circuit

The selection of HVDC technology type varies depending on the amount of power transmitted, the degree of control required and the price. LCC is a mature technology used for a long time. VSC is still in the development stage with a potential for improvement. Due to the equipment at the conversion station VSC is more expensive. VSC conversion stations have higher losses than LCC. Mircea and Philip (2017), by comparing the LCC and VSC conversion stations, LCC have lower losses $(0.5-1 \%)$ than VSC (1.8-3\%). Technical comparison of LCC and VSC shown in Table 3:

Table 3. Technical comparison of LCC and VSC.

\begin{tabular}{cc}
\hline LCC HVDC & VSC HVDC \\
\hline High power capacity & Low power capacity \\
Good overload capacity & Poor overload capacity \\
Creates harmonic distortion & Negligible harmonic generation \\
(AC and DC harmonic filter required) & (No filter required) \\
Requires converter transformer & Conventional transformer is used \\
Low station cost & High station cost \\
High reliability & Lower reliability due to the high number of \\
components & less mature technology \\
More mature technology & High Cost (10-15\%) \\
Low in cost &
\end{tabular}

Source: (Mircea and Philip, 2017).

Since there is no grounding, VSC technology is bipolar by nature. The disadvantage is that in the event of a malfunction or during periods of maintenance, the systems must be shut down completely without the possibility to disconnect the current from another pole and at least partially resume operation (Table 4). It is not currently possible to talk about VSC-HVDC interconnection which is has a long distance and a high capacity. However, this technology is thought to be able to compete with the classic HVDC in the coming years (Mircea and Philip, 2017). The choice of DC configuration is basically affected by the needed reliability, ratings, cost effectiveness and compliance with local policies and regulations. They are commonly used mono-pol and bipolar connections of HVDC transmission systems. Homo-polar 
connection types are rarely applied and mostly depend on the designs of other common. In contrast, to connect unsynchronized AC networks back-to-back configurations is preferred. For example, the AlFadhili project launched in 2009 to connect the Saudi Arabia system to neighboring markets (Kuwait, Qatar and Bahrain) with a total capacity of 1800 MW (Macleod et al., 2010; Li et al., 2014). Projects with current configuration data in the world reveal that 33\% are structured in B2B style. In most of these B2B connections, LCC converters are more widely used than VSC converters, as the LCC has less power loss (Van Hertem and Ghandhari, 2010).

Table 4. The comparison of converter types.

\begin{tabular}{|c|c|c|}
\hline & LCC & VSC \\
\hline & $\begin{array}{l}\text { The energy storage device needs } \\
\text { (capacitor). }\end{array}$ & $\begin{array}{l}\text { The energy storage device needs } \\
\text { (Inductor). }\end{array}$ \\
\hline $\mathrm{AC}$ & $\begin{array}{l}\text { Needs large AC filters. } \\
\text { Reactive power supply is required for } \\
\text { power factor correction. }\end{array}$ & $\begin{array}{l}\text { Needs small AC filters. } \\
\text { No power supply is required. }\end{array}$ \\
\hline DC & $\begin{array}{c}\text { Requires energy storage device (Inductor). } \\
\text { Requires DC filter. } \\
\text { Provides natural fault current limiting } \\
\text { feature. }\end{array}$ & $\begin{array}{l}\text { Requires energy storage device (capacitor). } \\
\text { The energy storage capacitor provides DC } \\
\text { filtering without paying additional cost. } \\
\text { As the charged capacitor will work the } \\
\text { problematic fault is discharged in DC line } \\
\text { side faults. }\end{array}$ \\
\hline Switching & Switching takes place at the line frequency. & Switching takes place at high frequency. \\
\hline
\end{tabular}
Source: (Sood, 2004).

The converter transformers according to the winding connections are as follows: I) single-phase, three windings. II) three-phase, three windings. III) single-phase, two windings. IV) three-phase, rotation. Transformer type directly affects transport size and convenience as an important selection criterion. Highlevel transformers are physically huge for high- powered applications and are impractical to carry to the field. Instead, option (III) is benefited frequently in HVDC applications since transformers are linked to three-phase arrangements at the station and maintain acceptable phase balancing and are easier to transport, which makes it easy to add replacement transformers on site at an acceptable cost for raised system reliability (Bancal, 2015). The properties of the converters used in HVDC and HVAC transmission lines are shown in Table 5 (Haugland, 2008). 
Table 5. Comparison of HVAC and HVDC transmission system converter.

\begin{tabular}{|c|c|c|c|}
\hline & HVAC & HVDC LCC & HVDC VSC \\
\hline $\begin{array}{l}\text { Maximum } \\
\text { usable } \\
\text { capacity }\end{array}$ & $\begin{array}{l}\text { at } 400 \mathrm{kV} 800 \mathrm{MW} \\
\text { at } 220 \mathrm{kV} 380 \mathrm{MW} \\
\text { at } 132 \mathrm{kV} 220 \mathrm{MW} \\
\text { all up to } 100 \mathrm{~km}\end{array}$ & $\begin{array}{c}\text { up to } 600 \mathrm{MW} \text { (submarine } \\
\text { transmission) }\end{array}$ & $\begin{array}{c}\text { Installed up to } 350 \mathrm{MW}, \\
800 \mathrm{MW} \text { is being } \\
\text { developed. }\end{array}$ \\
\hline Voltage level & $\begin{array}{c}132 \mathrm{kV} \text { installed } \\
220 \text { and } 400 \mathrm{kV} \text { are being } \\
\text { developed. }\end{array}$ & $800 \mathrm{kV}$ and above & $\pm 300 \mathrm{kV}$ \\
\hline $\begin{array}{l}\text { Black-start } \\
\text { functionality }\end{array}$ & Yes & No & Yes \\
\hline $\begin{array}{l}\text { Maintenance } \\
\text { requirements }\end{array}$ & Low & High & Medium \\
\hline Cable model & Resistance, reactance & Resistance & Resistance \\
\hline $\begin{array}{l}\text { Installation } \\
\text { costs }\end{array}$ & $\begin{array}{l}\text { Low for station (only } \\
\text { transformer) } \\
\text { High cost for cable } \\
\end{array}$ & $\begin{array}{l}\text { High cost for station } \\
\text { Low costs for cable }\end{array}$ & $\begin{array}{l}\text { The station is } 30-40 \% \\
\text { more expensive than } \\
\text { LCC. }\end{array}$ \\
\hline $\begin{array}{l}\text { Equipment } \\
\text { costs }\end{array}$ & $\begin{array}{l}\text { It is expected to be less } \\
\text { than } 75 \mathrm{~km} \text {. Reactive } \\
\text { compensation and } \\
\text { resulting platform cost } \\
\text { increase for higher } \\
\text { distance and power. }\end{array}$ & $\begin{array}{c}\text { Similar to VSC but } \\
\text { additional cost for reactive } \\
\text { compensation and less } \\
\text { compact, thus higher } \\
\text { platform costs }\end{array}$ & $\begin{array}{l}\text { Recently, VSC costs have } \\
\text { become similar to LCC } \\
\text { costs. VSC is more } \\
\text { compact, so the platform } \\
\text { cost is lower. }\end{array}$ \\
\hline Power loss & $\begin{array}{l}\text { The losses from the cable } \\
\text { are directly proportional } \\
\text { to the distance }\end{array}$ & $\begin{array}{c}\text { Approximately } 3.3 \% \\
\text { conversion losses and } \\
\text { cable losses proportional } \\
\text { to distance }\end{array}$ & $\begin{array}{c}\text { Approximately } 1.5 \% \\
\text { conversion losses and } \\
\text { cable losses proportional } \\
\text { to distance }\end{array}$ \\
\hline
\end{tabular}

Source: (Ackerman, 2005; Raza et al., 2017).

\subsubsection{Filters (AC-DC)}

Related with AC and DC filters, AC filter is linked to AC side of converter transformer and DC filter is linked to DC side in the same way. While the purpose of the use of AC filter is to prevent harmonics and high frequency components entering the system, DC filters prevent the inference of harmonic voltages in the transmission line where the currents overlaps and create noise (Ai and Tin, 2014). If they are not filtered, cause capacitors and adjacent generators to overheat.

\subsubsection{Converters (VSC Thyristor)}

Conversion between AC-DC and DC-AC is provided by converter valves. Thyristor consist of valve bridges and step-changing transformers. Valve bridges consist of six pulse or twelve pulse valves depending on the arrangement. The converter transformer supplies an ungrounded 3-phase voltage source to the value bridge. When the value samples are examined, mercury arc value, thyristor value and VSC valve appear. In VSC value thyristor, current harmonics on the AC side are directly related to the PMW frequency, as it must compensate for any reactive power consumed by it. Thus, it significantly reduces the amount of filter required (Kundur, 1994; El-Saady et al., 2016). 


\subsubsection{Reactive power source}

Reactive power supply, which is important for maintaining voltage balance in a large-scale transmission system, is used to meet the reactive power requirement, develop voltage profiles and reduce network loss. The converter stations absorb reactive power during operation. The reactive power absorbed in the stationary operation is approximately $50 \%$ of the transmitted active power. This percentage raises under temporary conditions and thus reactive power supplies are normally provided near transducers (Kundur, 1994; Machado et al., 2015).

\subsubsection{Electrodes}

To provide a neutral connection to ground and reduce current densities, large surface conductors are normally employed. Conductors connected in this way are called electrodes. However, it is recommended to limit the current flow in the world, and therefore metallic return conductors are used for this purpose (Azimoh, 2010).

\subsubsection{Corrective Reactor}

The smoothing reactor placed on the DC line reduces the fluctuations in the DC current and prevents current leakage in case of failure (Gamit et al., 2015). The functions of these high inductance large reactors can be listed as follows:

- Reduce peak current of the rectifier in the DC line faults.

- Prevents commutation failure.

- Decreases the harmonics in DC line.

\section{TECHNICAL AND ECONOMIC PERFORMANCE EVALUATION OF HVDC}

HVDC transmission systems have many advantages in terms of cost and transmission losses against HVAC systems as far as long-distance transmission line is concerned (Okba et al., 2012; Xiong et al., 2017):

- Simple and smaller transmission towers.

- Narrower right of way

- Requires only one-third of the isolated conductor sets as double-circuit AC lines.

- Operated independently of each conductor circuit.

- No charge current exists in steady state.

- Less loss since there is no skin effect.

- No reactive compensation required.

- Distances are not limited to stability.

- Short circuit current is very low.

- It does not contribute to the short circuit current of an AC system.

- For underground or submarine cables, there are no physical restrictions that limit the distance or power level.

\subsection{Technical Performance Assessment of HVDC}

The fast-controllable structure of HVDC transmission lines provides an advantage in providing full control over the transmitted power. The DC line connected to AC increases the transmission and dynamic stability of the line. The angle difference between the voltage phasor at the beginning and end of an AC line affects power transfer. As the distance increases, the increasing angle difference limits the stability of the transient states for maximum power transmission. Power carrying capacity in line AC 
varies with inverse proportion depending on the length of the line. DC lines are capable of carrying power regardless of the length of the line. Voltage control on the AC line is more difficult than on DC lines. The reason for this is that reactive power is required as the load on the line increases to provide constant voltage at the beginning and end of the line. Whereas DC lines themselves do not need reactive power control directly (Barthold, 2006; Kharade and Savagave, 2017; The Crown Estate, 2008). For the increase in power transfer and voltage control in long AC transmission lines, static VAR compensator (SVC) and static compensator of the shunt reactor and serial capacitor are required, while such compensations are not required from DC lines. High ground impedance in AC, both effects the efficiency of power transfer and causes interference. Whereas in DC, the ground impedance can be neglected by using a single conductor with mono-polar link system. Even when working with mono-polar link in DC transmission line systems, the AC network feeding the DC converter station operates with balanced currents and voltages. In this case, a single-phase system in AC cannot be implemented for more than one second, while, long-term operation can be achieved even with a single pole in DC (Mircea and Philip, 2017).

\subsubsection{Cables}

When the applicability of DC lines is examined; in case of using long cable links exceeding approximately $40-50 \mathrm{~km}$ break-even distance, DC cable and energy transmission system is advantageous compared to AC cable link system. In recent years, the use of VSC and durable polymer DC cables has become increasingly common.

Large power transmission over long distances creates an economic advantage over AC when breakeven point is exceeded. Projects starting from the Pacific link line to China and India can be exemplified in this sense. Due to the impact of developments in power electronics switching systems, in the development of new compressed converters, which decreases the costs appears to have reduced the break-even point for DC link. Load flow control of AC connections is difficult in large interconnected connections. This difficulty is overcome thanks to the fast control power and time-dependent overload capacities of the DC (Sood, 2004).

High-voltage AC cables have much greater shunt capacitance than overhead transmission lines per $\mathrm{km}$. For long distances, the capacitance grows and the reactive current required to charge the cable approaches the rated current, leaving less current capacity to transmit active power, causing the cable to decelerate. Over a certain distance, real power transmission becomes impossible. Shunt capacitance of an AC cable must be met by distributed balancing across the cables. However, this is not possible in marine transmission and shunt reactors or STATCOMs are used at both ends (Normark and Nielsen, 2005).

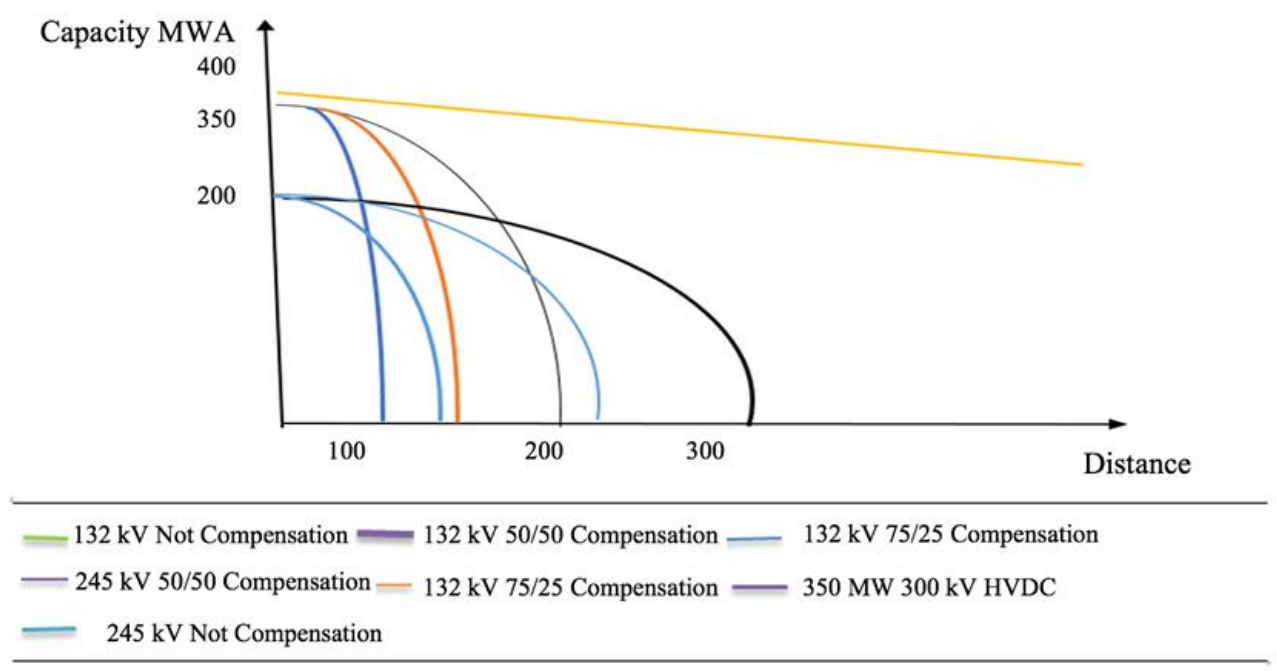

Figure 6. HVAC and HVDC cable comparison (Sood, 2004). 
DC cables, on the other hand, do not produce or consume any reactive power and their active power capacity almost does not damage the distance. In addition, AC cables have insulator losses and skin effect unlike DC cables. Economically, DC cables are less costly than AC cables with the same voltage and power rating. When using an $\mathrm{AC}$ cable, the change in the reactive consumption of the cable with the transmitted power is a problem. Cable operation will be at a relatively stable operating point, if it can be compensated before reaching a point where the transfer capacity of the cable is fully utilized (Mirebeau and Syrtveit, 2015; Ye et al., 2018).

There are two types of cables commonly used in HVDC transmission line systems. The first one is Mass Impregnated (MI) cables. This cable system was first used in 1954 at $100 \mathrm{kV}$ HVDC project in Gotland, Sweden (ABB, 2014). The insulation system of MI cables can be described as lapped paper tapes impregnated with an adhesive, oily compound. This cable system can be used with both VSC and LCC converters. Extruded HVDC cables are another type of DC cable that is more sustainable and flexible alternative to MI cables. This type of cable was initially used in HVDC transmission line systems in 1999 (Bergelin et al., 2017). In extruded HVDC cables, the insulation material is based on cross-linked polyethylene (XLPE). Therefore, these cables are called XLPE cables. XLPE cables are employed mainly in VSC-HVDC links since they tend to fail because of excessive DC voltage, as opposed to power flow when used in LCC-HVDC links. The advantages of XLPE cables compared to MI cables can be listed as follows (Gu et al., 2018; Zeng et al., 2018) and seen in Table 6:

- $\quad$ Easy to carry, low weight and design flexibility.

- Mechanical strength.

- $\quad$ Fast production process.

- Being environmentally friendly without using recyclable materials.

Considering the advantages of XLPE cables over MI cables, it is expected that HVDC will have a major stake in the transmission line systems market in the future.

Table 6. Comparison of XLPE and MI cable technologies.

\begin{tabular}{lll}
\hline Cable Type & MI & XLPE \\
\hline Isolation Type & Paper/Oil & Polymer \\
\hline First Use in HVDC & 1954 & 1999 \\
\hline HVDC Application & LCC/VSC & VSC \\
\hline Mechanical Weight/ Isolation & High / Hard & Low / Soft \\
\hline Longest Distance & $580 \mathrm{~km}$ & $400 \mathrm{~km}$ \\
\hline Maximum Power & $2200 \mathrm{MW} / \pm 600 \mathrm{kV}$ & $2000 \mathrm{MW} / \pm 320 \mathrm{kV}$
\end{tabular}

Source: (Pipelzadeh et al., 2015; Francos et al., 2012; Murata et al., 2013; Mokhberdoran et al., 2017; Vrana and Energi, 2016).

Figure 7 shows the specification of MI and XPLE cables that used in a HVCD line. 


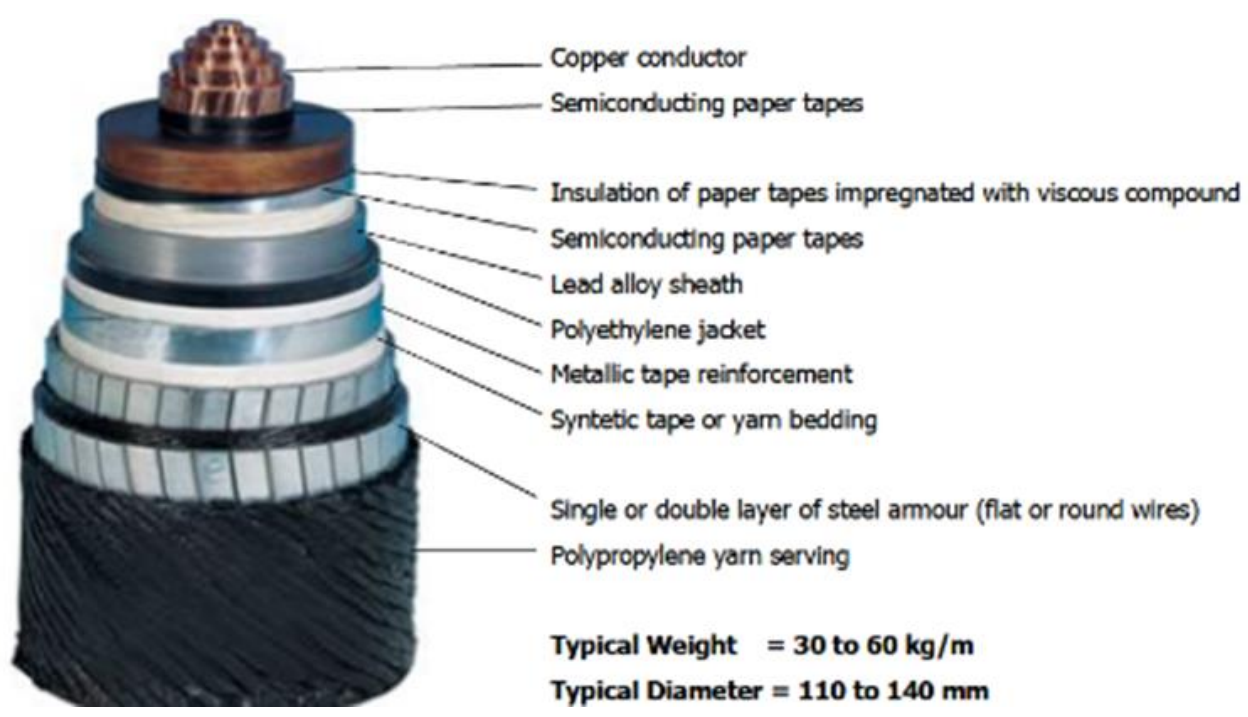

(a)

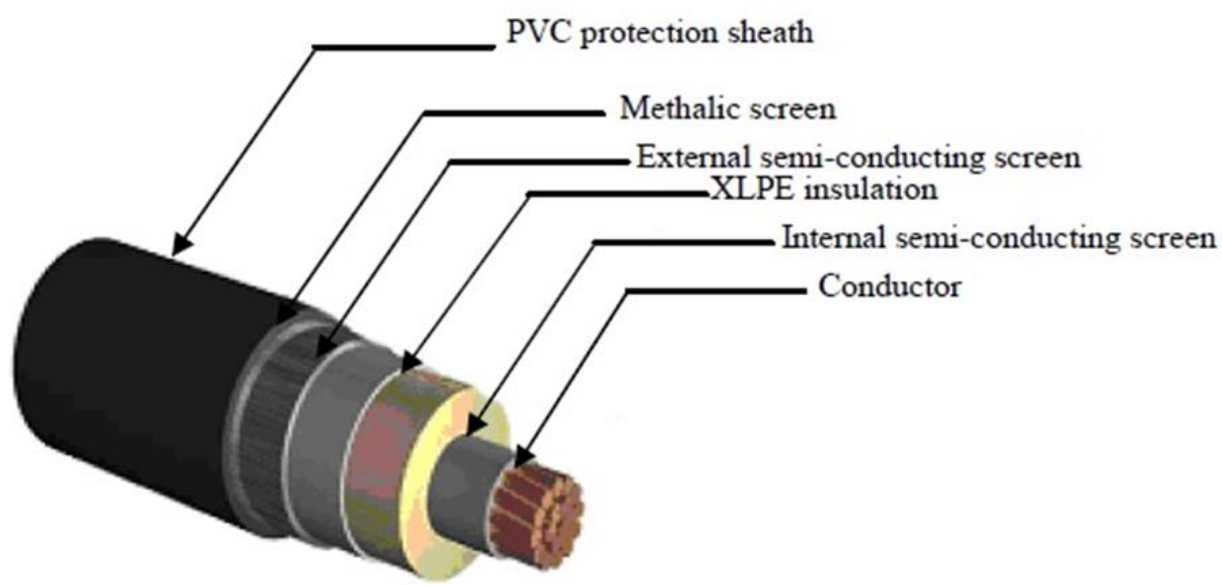

(b)

Figure 7. a) MI cable. b) XPLE cable.

Insulators Used in Overhead Lines: Different types of insulators are used in overhead lines according to the voltage value.

Pin Type Insulator: This isolator is used in transmission or distribution networks up to $33 \mathrm{kV}$. Insulator can be one piece, two pieces or three pieces, depending on the voltage level. At voltages higher than 33 $\mathrm{kV}$, it is very difficult to make a single piece of porcelain due to the increase in insulator thickness. In this case, a multi-piece pin type insulator must be designed. Figure 8 shows the $33 \mathrm{kV}$ pin type insulator. 


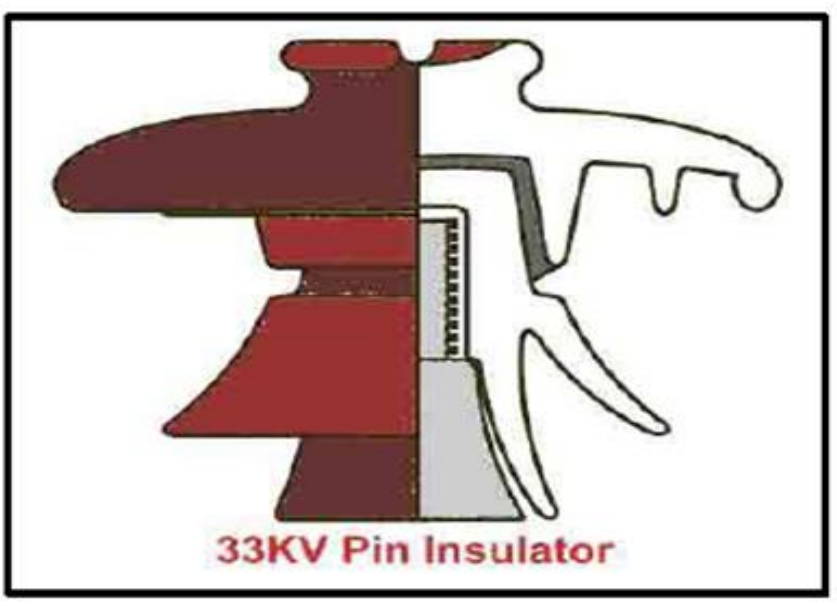

Figure $8.33 \mathrm{kV}$ Pin type insulator

Post Type Insulators: Post insulators are used for higher voltages compared to pin insulators. Especially in high or medium voltage lines, this type of insulator is highly preferred. These insulators are the group A that specified in IEC 60383, in other words, they are puncture-proof Air Line Support Insulators. This insulator has more combinations and is much higher. Post insulators can be mounted horizontally and vertically on the supporting structure. Figure 9 shows the post type insulator.
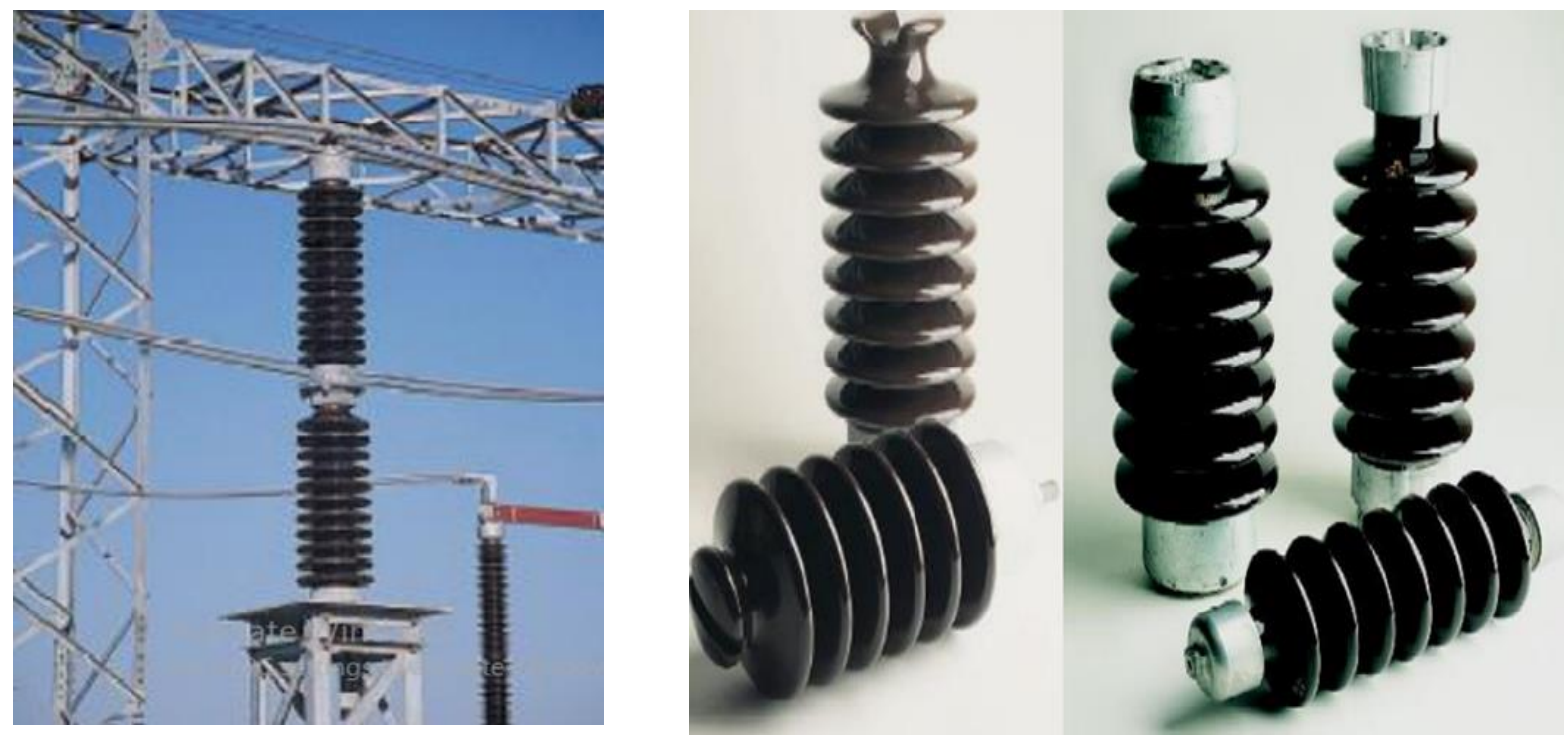

Figure 9. Post type insulator

String Insulators: These types of insulators are used to fix the conductor in medium and high voltage energy transmission and distribution lines by hanging or stretching the conductor. Insulators in the production program are divided into groups shown below.

- Normal type chain insulators with ball and socket joint

- Chain insulators used in dirty areas (fog type) with ball and socket joints

These types of insulators are connected together in series to form a string and the line conductor is carried by the lowest insulator. Because of its disc type shape, each insulator of a suspension rope is 
called a disc insulator. A very high level of mechanical strength and electrical insulation properties are required in string insulators.
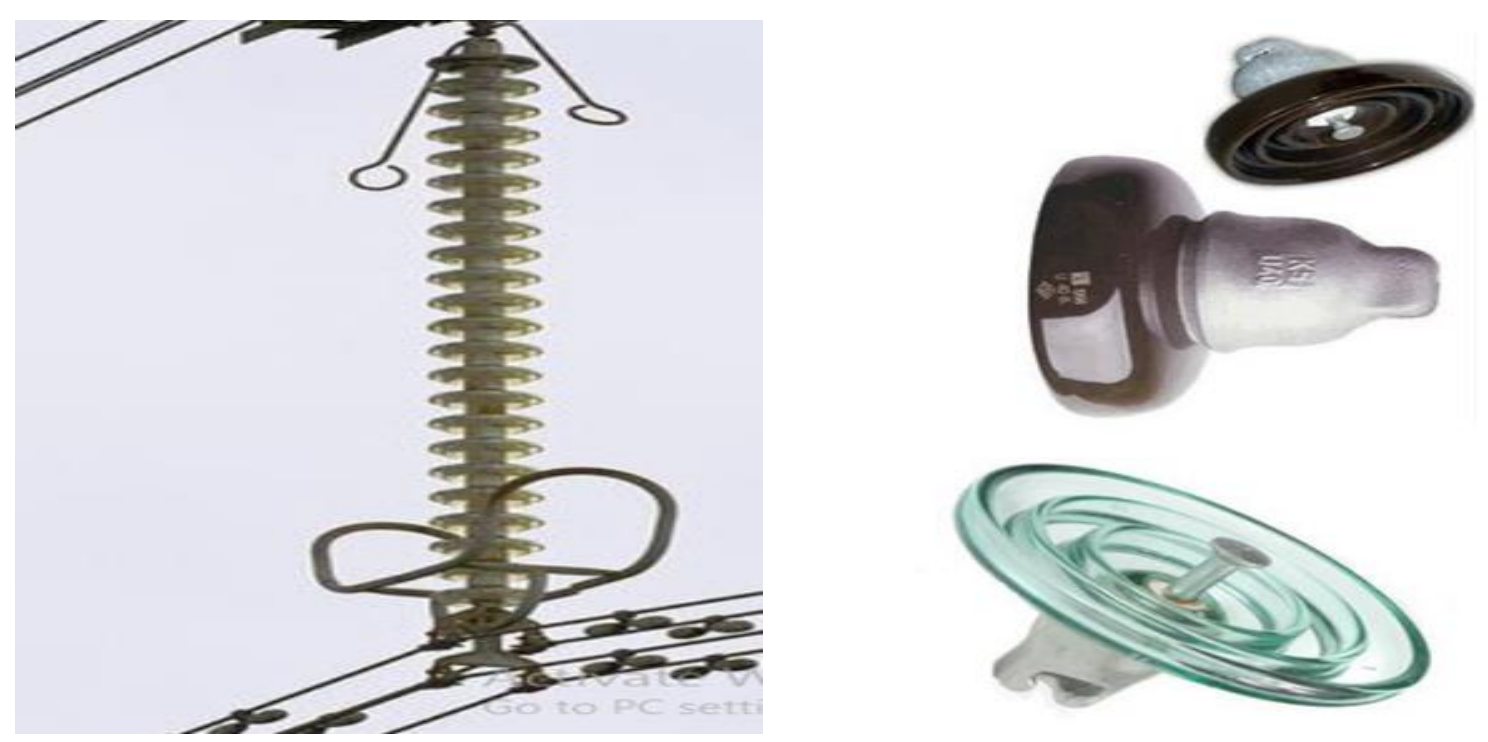

Figure 10. String type insulator

\subsection{The Evaluation of Economic Performance}

When HVAC and HVDC are compared economically, we encounter with three cost components:

- The terminal cost

- The line cost

- The Losses cost

The total cost is divided into two as the cost to establish the infrastructure and the cost to run the system when it becomes functional. It takes into account investment cost, poles, conductors and insulations, converter stations and the right of way usage. The operating cost particularly includes losses expressed financially. 


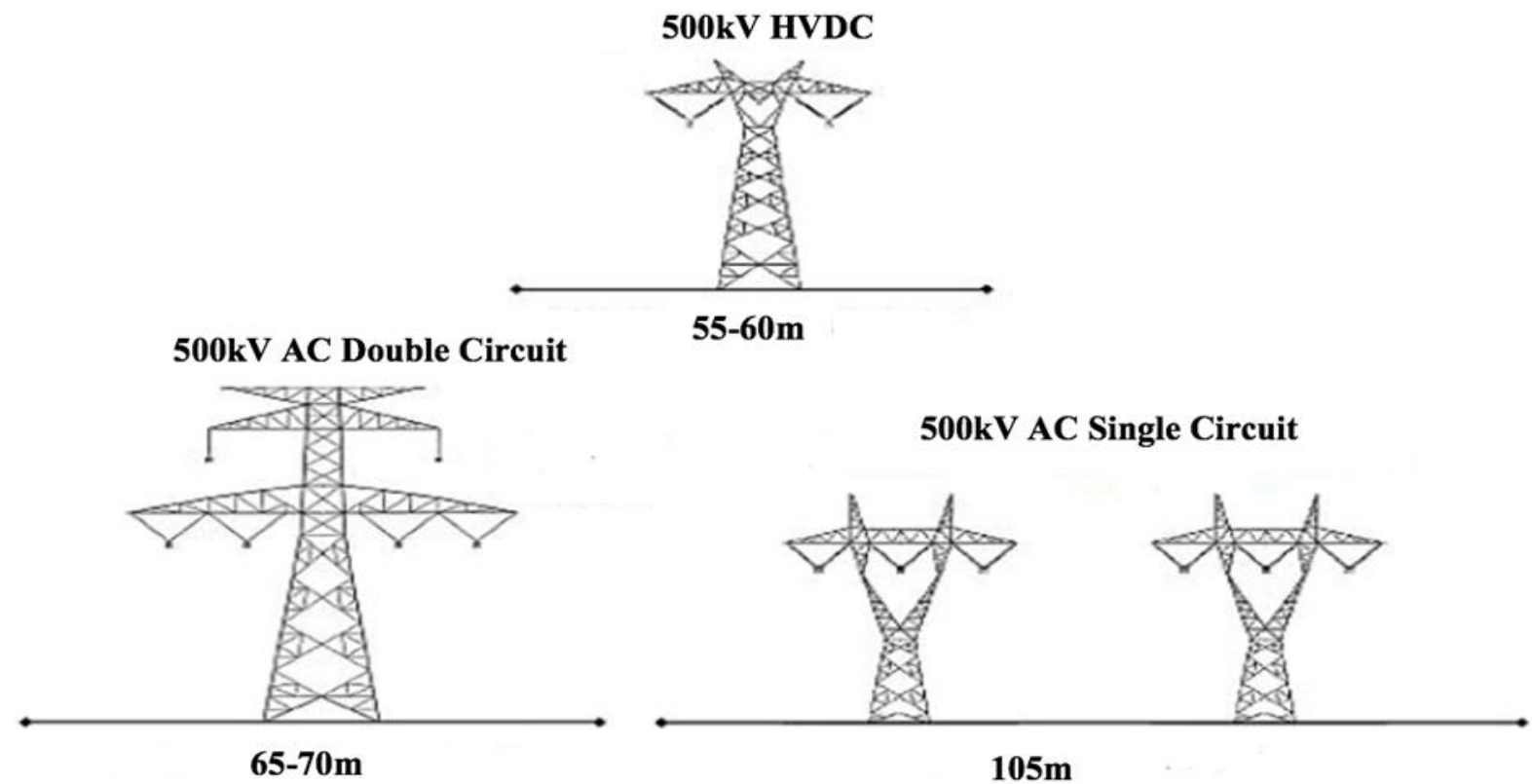

Figure 11. The comparison AC and DC right of way (ROW) (Mircea and Philip, 2017).

ROW size varies between AC and DC line. In particular, this difference creates a significant discrepancy in costs when crossing densely populated areas with high land value. Kumru and Arıan (2020) suggest safe ROW distances. For the same power capacity, DC ROW can be half the width of AC (Figure 11). Assuming that the conductor and insulation types are the same for AC and DC, AC needs three conductors for the same voltage, while DC needs two conductors (Pletka et al., 2014). Thus, DC poles turn into a narrower passageway which requires less material for conductors and insulators (Mircea and Philip, 2017). In addition, the fact that DC needs two conductors instead of AC needs three conductors, indicates that DC losses are $2 / 3$ of the $\mathrm{AC}$ losses. Considering the very long mileage distances, losses in AC lines gain great importance. In Figure 12, AC and DC transmission line losses are calculated as follows (Kalair et al., 2016; May et al., 2016):

$$
\begin{aligned}
& \text { Power transmitted by DC }=V_{d} I_{d} \\
& \text { Power transmitted by AC }=3 V_{a} I_{a} \cos \theta \\
& \text { DC power loss }=2 I_{d}^{2} \mathrm{R} \\
& \text { AC power loss }=3 I_{a}^{2} \mathrm{R}
\end{aligned}
$$

When the transmission losses of $\mathrm{AC}$ and DC in equations (3) and (4) are equalized, equation (5) is achieved.

$$
2 I_{d}^{2} \mathrm{R}=3 I_{a}^{2} \mathrm{R} \rightarrow \frac{I_{a}}{I_{d}}=\sqrt{\frac{2}{3}}
$$

When using DC instead of three phase AC, under the assumption of the same power transmission, the same conductor size and the same power loss; 


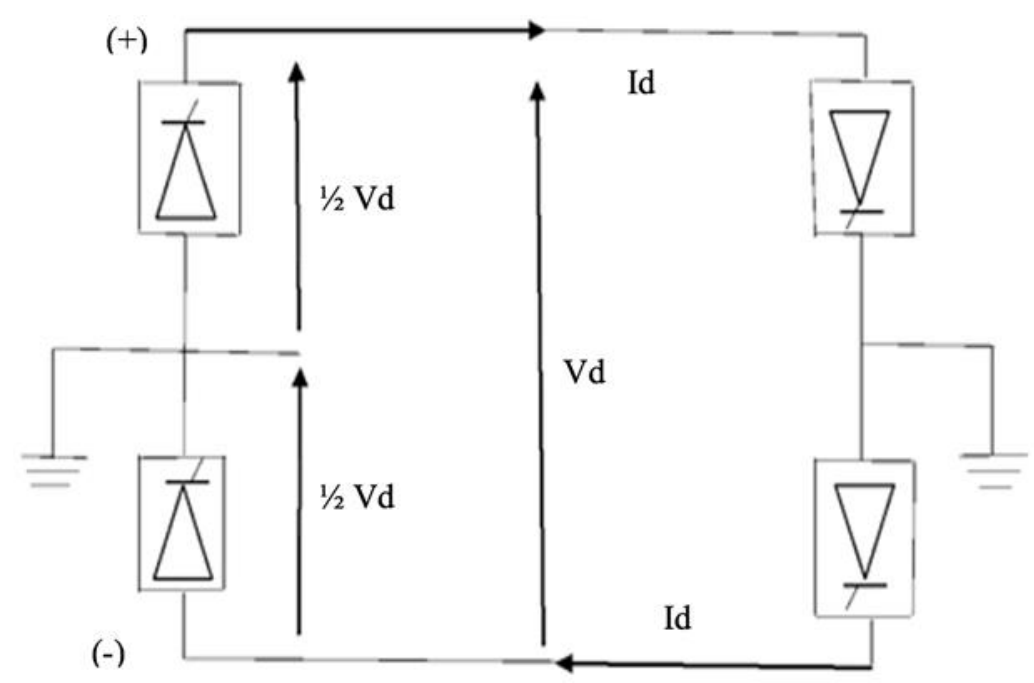

Figure 12. Conversion of three phase AC transmission line to DC transmission line (Kalair et al., 2016;

May et al., 2016).

In case the power transmitted on both sides is the same, the number (6) is obtained.

$$
3 V_{a} I_{a}=V_{d} I_{d} \rightarrow \frac{V_{d}}{V_{a}}=3 \frac{I_{a}}{I_{d}}=3 \sqrt{\frac{2}{3}}=\sqrt{6}
$$

Thus, the link between the AC installation level and the DC installation level is expressed in the equation number (7).

$$
\frac{\text { AC Instalation Level }}{\text { DC Installation Level }}=\frac{1}{2 \sqrt{2}} \frac{V_{d}}{V_{a}}=\frac{\sqrt{6}}{2 \sqrt{2}}=0.867
$$

When the 3-phase double circuit AC line is converted to 3-phase double circuit DC line, the relationship between the power transmitted by DC and the power transmitted by AC is expressed as equation (8).

3-phase double circuit AC line power transfer $=2\left(3 V_{a} I_{a} \cos \theta\right)$

3-phase double circuit DC line power transfer $=3 V_{d} I_{d}$

$$
\frac{\text { Power Transmitted by DC }}{\text { Power Transmitted by AC }}=\frac{3 V_{d} I_{d}}{6 V_{a} I_{a}}=\frac{3\left(2 \sqrt{2 V_{a}}\right)}{6 V_{a}} I_{a}=\sqrt{2}=1.414
$$

It is known that the diameter of the DC conductor is also different from AC. While AC uses only the peripheral part of the conductor, DC utilizes from the whole part of the conductor. Thus, with the same diameter conductor, DC conducts $30-40 \%$ more electricity than AC, and it is clear that DC has become more efficient than AC (Meah and Ula, 2006). The unit cost of electrical energy transmitted with increased efficiency is less for DC. As seen in Figure 13, the requirement for converters and filters causes DC systems to be more costly. Nonetheless, fewer losses in DC transmission compensate for this cost, especially in terms of long distance (Elliott et al., 2015). In the AC and DC cost comparisons, it is seen that the break-even distance for break-even lines is 500-800 km (tending to fall 500-600 km) and $50 \mathrm{~km}$ less for submarine cables. While AC is profitable for short distances below the break-even distance, DC becomes profitable over the break-even distance for longer distances (Hur, 2012; EEP, 2014; Eltamaly et al., 2017). 


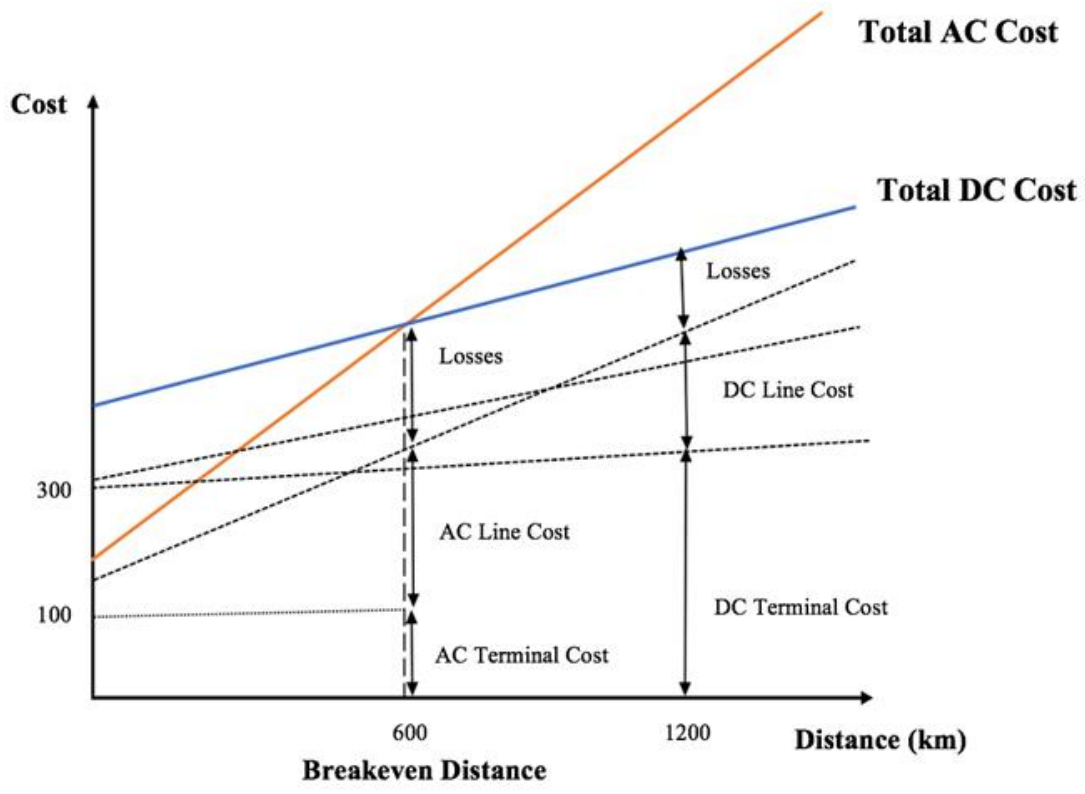

Figure 13. The cost comparison of HVAC and HVDC transmission systems (Elliott et al., 2015).

Since conversion stations are very costly, initial investment costs are higher for DC systems. However, since it requires smaller number of conductors and simpler and lighter poles, DC is more advantageous than $\mathrm{AC}$ in terms of the cost of the transmission line, especially in long distances (Chen et al., 2015). In addition, the fact that DC's losses are less than AC for long distances compensates for the first station cost that occurred at the beginning and DC appears as a less costly and efficient transmission system over time.

\subsection{A Technical Comparison and Discussions}

\subsubsection{A Technical Comparison: Investment Costs of the Transmission System}

The investment cost of the transmission system is separated into various components for both HVAC and VSC HVDC options which can be seen in the first column of the Table 7 (Van Eeckhout et al., 2010). As it is seen from Table 7, the substation cost is higher for the VSC HVDC against HVAC due to the IGBT-based DC/AC converters (phase reactors, power electronics, filters, enclosed valves, transformers, etc.). A substation is required for both ends of the transmission cable in each technology. The price of the bipolar HVDC cable-pair for transporting the equal amount of active-power is less than the price of the two-parallel three-core HVAC cables. The DC cables do not require three phases in one cable, which makes them less complex, they have lower insulation and symmetry requirements, and they need less conductor surface of transported power per unit. The market price of cables is affected by the volatile characteristic of the price of copper.

Table 7. A comparison for the prices of the transmission systems for $300 \mathrm{MW}$ offshore wind farm in

\begin{tabular}{|c|c|c|}
\hline Item & HVAC & VSC HVDC \\
\hline Substation (M€) & 10 & 45 \\
\hline Cable $(\mathbf{k} € / \mathbf{k m})$ & 1500 & 600 \\
\hline Cable Installation $(\mathbf{k} € / \mathbf{k m})$ & 340 & 215 \\
\hline Offshore Substation Rig (M€) & 13 & 24 \\
\hline Onshore Land Use (k€) & 50 & 125 \\
\hline
\end{tabular}

Source: (Van Eeckhout et al., 2010). 
The installation cost of DC cables is lower than the installation cost of AC cables. Moreover, their installation is easier due to the flexibility of the cables (single core vs. three-core) and they have thinner construction for the cable insulation. As a protection from the submarine environment both cable technologies are buried 1 meter deep in the seabed that is a general standard for undersea transmission protocol. The cost of substation platform which depends on the volume is assumed to be $1000 € / \mathrm{m}^{3}$ for the offshore rig. The installation of a DC/AC converter needs more space than an AC station, leading a higher rig cost for the VSC-HVDC. On the other hand, the onshore land utilization is a minor transmission system cost that depends on the type of surface (Van Eeckhout et al., 2010).

\subsubsection{Discussions}

Energy, an important indicator of welfare with its economic, social and environmental dimensions, is an important production input. Rapid population growth, urbanization, industrialization and production increase in the world are increasing the demand for energy day by day. It is very important for each country to determine a separate domestic and foreign policy for energy production and consumption in order to provide energy, which is in almost every area of our lives in the 21st century. Today, the dynamic nature of international balances and the asymmetric distribution of energy resources around the world bring with it the energy supply security problem for countries with high foreign dependence on energy. In world economies where efforts to increase economic welfare intensify, foreign dependence on energy is increasing in parallel with the production levels. The increase in foreign dependency on energy affects the economy negatively through causing an increase in the current account deficit, an important import item in the countries. For this reason, countries need to raise their current capacity and efficiency to reduce the foreign dependency on energy and to overcome the energy supply problem.

While developed countries often have sufficient economic power in terms of increasing existing capacity and energy efficiency investments, this may not be possible for developing countries due to economic difficulties. For this reason, it is thought that in developing countries obtaining high efficiency from their existing capacities will accelerate the studies about planned capacity increase. HVDC transmission line technologies have come to the fore in national and international connections among the steps taken in energy efficiency in recent years. Among the steps taken in energy efficiency in recent years, HVDC transmission line technologies in national and international connections have come into prominence. The rapid advancement of HVDC transmission line systems in the last five decades in the world is due to their technological and economic advantages compared to HVAC transmission line systems. It is seen that HVDC transmission line systems provide around $40 \%$ higher efficiency than HVAC transmission line technologies due to less cost and transmission loss. In Turkey, a developing country with a high dependency on foreign energy, HVDC transmission line systems are predicted to have a leading role in reducing dependency on foreign energy by ensuring energy efficiency. The agreement with an important service provider, ENTSA-E CESA, in the market of HVDC transmission line systems in Turkey is expected to accelerate the infrastructure operations of the HVDC transmission line systems. Thus, within the scope of 2019-2023 energy strategies, it is expected to create opportunities in terms of accessibility to energy at national and international level, energy efficiency and reduction of foreign dependency on energy.

\section{CONCLUSIONS}

In this study, the technological and economic superiorities of HVDC transmission line systems compared to HVAC transmission line systems and sample applications in the world are analyzed. In line with this framework, it presents the components, market structure, current situation in the world and in Turkey, and future trends of HVDC transmission line systems with a contemporary look. Findings obtained by examining the literature in detail can be listed as follows: LCC converters are widely used in HVDC transmission line systems compared to VSC converters in terms of available capacity. In cable 
structures, XLPE cable is preferred more than MI cable. It is expected that, in HVDC transmission line systems, MTDA connections will have a crucial role in the future with their outstanding advantages over other connection types. When the geographical distribution of HVDC transmission line systems is examined, it is seen that the Asian continent is in the first place. The continent of Asia is followed by Europe, North America, South America and other continents respectively.

Although, there are studies that focus on the reduction of the size and cost of the HVAC systems (Özcan, 2018) and model the underground high voltage cables (Akbal, 2017), the national and international levels of HVDC transmission line system is still not a mature technology and is yet to be seen in the development stage in Turkey. Thereby, a technical comparison example is given for investment costs of the transmission system for $300 \mathrm{MW}$ offshore wind farm in Germany. It is believed that HVDC transmission technology and related investments and ancillary services operating with renewable energy will be in Turkey in a close future.

The spread of HVDC transmission line systems worldwide due to low cost and high efficiency advantages over long distances is of great importance in terms of meeting the increasing energy demand and energy corridors that will be formed with international connections. It is thought that the development of HVDC transmission line systems, especially in countries that import a large part of its energy, will contribute to a reduction in imports due to increased efficiency and to decrease the import effect on the current account deficit indirectly. It is expected that having easy access to energy through international connections with the effect of decreasing costs and increasing efficiency will be facilitated in favor of price fluctuations in the international energy market. Considering the mentioned advantages, it is thought that evaluating the effect of rapidly growing HVDC transmission line systems on energy demand in terms of cost and losses will be a solution for energy efficiency in countries with high foreign dependency on energy, particularly in Turkey. In addition, this assessment is important in terms of determining the opportunities of HVDC transmission line systems that are planned to be established in the future.

\section{REFERENCES}

ABB, 2014, Review Special Report 60 Years of HVDC, https://searchext.abb.com/library/Download.aspx?DocumentID=9AKK106103A8195\&Languag eCode=en\&DocumentPartId=\&Action=Launch , Access Date: 12.04.2020.

Ackerman, T., 2005, Wind Power in Power System, $2^{\text {nd }}$ Ed. UK, John Wiley \& Sons.

Ai, P., Tin, T., 2014, "Design Implementation of 250kV HVDC Overhead Transmission System", International Journal of Scientific Engineering and Technology Research, Vol.3, No.15, pp. 32233227.

Akbal, B., 2017, "Forecasting Applications of the Sheath Current of High Voltage Cable with Artificial Neural Network Based Hybrid Methods", Pamukkale University Journal of Engineering Sciences, Vol.23, No.2, pp. 119-125.

Alassi, A., Banales ,S., Ellabban, O., Adam, G., Maclver, C., 2019, "HVDC Transmission: Technology Review, Market Trends and Future Outlook", Renewable and Sustainable Energy Reviews, vol. 112, pp. 530-554.

Almgren, B., Urban, A., Dong, W.,"A Survey of the Flashover Performance of HVDC Converter Station Insulators", IEEE 1998 International Conference on Power System Technology, Beijing, China, 516-519, 18-21 Auqust 1998.

Azimoh, L.,C., 2010, Investigation Into Voltage and Angle Stability of A Hybrid HVAC-HVDC Power Network, Master Thesis, University of Cape Town, South Africa.

Bahrman, MP., "Overview of HVDC Transmission", 2006 IEEE PES Power Systems Conference and Exposition, Atlanta, USA, 29 Oct-1 Nov 2006.

Bancal, S., 2015, Basic Design of An HVDC Interconnection in Brazil, Master Thesis, KTH Royal Institute of Technology, Stockholm, Sweden.

Barthold, L.,O., "Technical and Economic Aspects of Tripole HVDC", 2006 International Conference on 
Power System Technology, Chongqing, China, 22-26 October 2006.

Beerten, J., Gomis-Bellmunt, O., Guillaud, X., Rimez, J., Van Der Meer, A., Van Hertem, D., “Modeling and Control of HVDC grids: A Key Challenge for the Future Power System", IEEE 2014 Power Systems Computation Conference, Wroclow, Poland, 18-22 Auqust 2014.

Bergelin, P., Jeroense, M., Quist, T., Rapp, H., 2017, “640 kV Extruded HVDC Cable System”. Technical Report, NKT Group GmbH.

Bertling, L., Pramod, B., "On the Use of Reliability Test Systems: A Literature Survey", 2011 IEEE Power and Energy Society General Meeting, Michigan, USA, 1-9, 24-28 July 2011.

Brask, M., 2008, Modelling of The Power System of Gotland Inpss/E With Focus on HVDC Light, Master Thesis, KTH Royal Institute of Technology, Stockholm, Sweden.

Brenna M, Foiadelli F, Longo M. "Fault Detection HVDC Systems Applied to Renewable Sources". 17th International Conference on Electronic. Belo Horizonte, Brazil, 16-19 Oct 2016.

Burger, N., Tuson, P., 2005, “Loadflow Modelling of a 400 km 2000 MW HVDC Link", Energize, pp. 28-34.

Cao, J., Cai JY., "HVDC in China", EPRI 2013 HVDC\&FACTS Conference, Palo Alto, CA, USA, 28-29 August 2013.

Chen, G., Hao, M., Xu, Z., Vaughan, A., Cao, J., Wang, H., 2015, “Review of High Voltage Direct Current Cables", CSEE Journal of Power and Energy Systems, Vol.1, No.2, pp. 9-21.

Cotts, BR., Prigmore, II. JR., Graf, KL., 2017, “HVDC Transmission for Renewable Energy Integration”, in The Power Grid, Academic Press, 171-196.

EEP, 2014, Electrical Engineering Portal, https://electrical-engineering-portal.com/analysing-the-costs-ofhigh-voltage-direct-current-hvdc-transmission, Access Date: 15.03.2020.

Elliott, D., Bell, KR., Finney, S., J., Adapa, R., Brozio, C., Yu, J., Hussain, K., 2015, “A Comparison of AC and HVDC Options for the Connection of Offshore Wind Generation in Great Britain", IEEE Transactions on Power Delivery, Vol.31, No.2, pp. 798-809.

El-Saady, G., Ibrahim, EA., Okilly, A., H., "Analysis and Control of HVDC Transmission Power System", 2016 Eighteenth International Middle East Power Systems Conference (MEPCON). Cairo, Egypt, 27-29 December 2016.

Eltamaly, AM., Sayed, Y., Elghaffar, ANA., 2017, "A Survey: HVDC System Operation and Fault Analysis", Annals of the Faculty of Engineering Hunedoara-International Journal of Engineering, Vol. 15, No.4, pp. 25-30.

Figueroa-Acevedo, AL., Czahor, M., Jahn, DE., 2015, “A Comparison of the Technological, Economic, Public Policy, and Environmental Factors of HVDC and HVAC Interregional Transmission", AIMS Energy, Vol. 3, No. 1, pp. 1-18.

Francos, PL., Verdugo, SS., Álvarez, HF., Guyomarch, S., Loncle, J., “INELFE - Europe's First Integrated Onshore HVDC Interconnection", 2012 IEEE Power and Energy Society General Meeting, San Diego, California, 23-26 July 2012.

Gamit, P., Shah, N., Wani ,U., Patel, P., Mali, U., Chaudhari, A., 2015, "Comparative Analysis of HVDC and EHVAC", International Research Journal of Engineering and Technology (IRJET), Vol. 2, No. 9, pp. 1165-1171.

Giraneza, M., 2013, High Voltage Direct Current (HVDC) in Applications for Distributed Independent Power Providers (IPP), Master Thesis, Cape Peninsula University of Technology, Cape Town, South Africa.

Gu, X., He, S., Xu, Y., Yan, Y., Hou, S., Fu, M., 2018, “Partial Discharge Detection on 320 kV VSCHVDC XLPE Cable with Artificial Defects Under DC Voltage", IEEE Trans Dielectr Electr Insul, Vol.25, No. 3, pp. 939-946.

Haugland, P., 2008, "It's Time to Connect: Technical Description of HVDC Light ${ }^{\circledR}$ Technology", ABB Techincal Report, Ludvika, Sweden.

Hausler, M., "Multiterminal HVDC for High Power Transmission in Europe", CEPEX99 Conference, Poznan, Poland, March 1999.

Hur, D., 2012, "Economic Considerations Underlying the Adoption of HVDC and HVAC for the 
Connection of an Offshore Wind Farm in Korea", Journal of Electrical Engineering \& Technology, Vol.7, No.2, pp. 157-162.

IEEE, 2006, DC and Flexible AC Transmission Subcommittee of the IEEE Transmission and Distribution Committee by the Working Group on HVDC and FACTS Bibliography and Records, http://www.ece.uidaho.edu/hvdcfacts/Projects/HVDCProjectsListingDec2006.pdf Access Date: 15.04.2020.

Kalair, A., Abas, N., Khan, N., 2016, "Comparative Study of HVAC and HVDC Transmission Systems", Renewable and Sustainable Energy Reviews, Vol.59, pp. 1653-1675.

Kamalapur, GD., Sheelavant, VR., Pujar, A., Baksi, S., Patil, A., 2014, "HVDC Transmission in India", IEEE Potentials, Vol.33, No.1, pp. 22-27.

Kharade, JM., Savagave, DNG., 2017, "A Review of HVDC Converter Topologies", International Journal of Innovative Research in Science, Engineering and Technology , Vol. 6, No.2, pp. 1822-1830.

Kotb, O., 2018, On Stability Enhancement in AC/DC Power Systems through Multi-Terminal HVDC Controllers, Doctoral Thesis, KTH Royal Institute of Technology, Stockholm, Sweden.

Kumru, CF., Arıkan, O., 2020, "Investigation of Line Displacement in Terms of Electrical Field Distribution and Safe Right of Way Distance in Energy Transmission Systems", Pamukkale University Journal of Engineering Sciences, Vol.26, No.2, pp. 279-285.

Kundur, P., 1994, Power System Stability and Control, McGraw-Hill.

L'Abbate, A., Careri, F., Calisti, R., Rossi, S., Fulli, G., "Long-term HVDC Developments in the European Power System: The Baltic Case in GridTech Analysis", 2015 IEEE 5th International Conference on Power Engineering, Energy and Electrical Drives (POWERENG), Riga, Latvia, 11-13 May 2015.

Li, W., Shi, L., Yao, L., Zhao, Y., Jian, Z., Ni, Y., “Comparison of HVAC and HVDC Based Grid Integration on Wind Farm", 2014 International Conference on Power System Technology, Chengdu, China, 20-22 October 2014.

Liu Z., 2014, Ultra-High Voltage AC/DC Grids, 1sted., Waltham, USA, Academic Press.

Liu, Z., Zhang, F., Yu, J., Gao, K., Ma, W., 2018, “Research on Key Technologies in \pm 1100 kV Ultra-High Voltage DC Transmission", High Voltage, Vol. 3, No.4, pp. 279-88.

Long, W., Nilsson, S., 2007, "HVDC Transmission: Yesterday and Today", IEEE Power and Energy Magazine, vol. 5, No. 2, pp. 22-31.

Machado, J., Neves, MV., Santos, PJ., "Economic Limitations of the HVAC Transmission System When Applied to Offshore Wind Farms", 2015 9th International Conference on Compatibility and Power Electronics (CPE), Lisbon, Portugal, 24-26 June 2015.

MacLeod, NM., Barker, CD., Kirby, NM., "Connection of Renewable Energy Sources through Grid Constraint Points Using HVDC Power Transmission Systems", IEEE PES T\&D 2010, Sao Paulo, Brazil, 8-10 Nov 2010.

May, TW., Yeap, YM., Ukil, A., "Comparative Evaluation of Power Loss in HVAC and HVDC Transmission Systems", 2016 IEEE Region 10 Conference (TENCON), Singapore, 22-25 November 2016.

Mazzanti, G., Marzinotto, M., 2013, Extruded Cables for High-Voltage Direct-Current Transmission: Advances in Research and Development, Hoboken, New Jersey, JohnWiley \& Sons, Inc.

Meah, K., Ula, S., 2006, "Comparative Evaluation of HVDC and HVAC Transmission Systems", IEEE Power and Energy Magazine, Vol. 4, No.6, pp. 1-5.

Mircea, A., Philip, M., 2017, "A China-EU Electricity Transmission Link", Assessment of Potential Connecting Countries and Routes, EUR 29098 EN, Publications Office of the European Union, Luxembourg.

Mirebeau, P., Syrtveit, V., "Review of HVDC Insulated Transmission Cables Technologies", Jicable 2015, 9th International Conference on Insulated Power Cables, Versailles, France, 21-26 June 2015.

Mokhberdoran, A., Carvalho, A., Silva, N., Leite, H., Carrapatoso, A., 2017, "Application Study of Superconducting Fault Current Limiters in Meshed HVDC Grids Protected by Fast Protection 
Relays", Electric Power Systems Research, Vol. 143, pp. 292-302.

Murata, Y., Sakamaki, M., Abe, K., Inoue, Y., Mashi, S., Kashiyama, S., Katakai, S., 2013, “Development of High Voltage DC-XLPE Cable System", SEI Tech. Rev, Vol, 76, No. 1, pp. 55-62.

Normark, B., Nielsen, EK., "Advanced Power Electronics for Cable Connection of Offshore Wind", Offshore Wind Conference, Copenhagen, Denmark. 26-28 October 2005.

Okba, MH., Saied, MH., Mostafa, MZ., Abdel-Moneim, TM., “High Voltage Direct Current TransmissionA Review", Part I, in Proc. EnergyTech., IEEE, Cleveland, OH, U.S. 29-31 May 2012.

Özcan, H., 2018, “Thermodynamic Analysis of an Ice Slurry Thermal Energy Storage System for Decreased Size and Cost of HVAC Systems", Pamukkale University Journal of Engineering Sciences, Vol. 24, No.1, pp. 25-29.

Pipelzadeh, Y., Chaudhuri, B., Green, TC., Adapa, R., “Role of Western HVDC Link in Stability of Future Great Britain (GB) Transmission System", 2015 IEEE Power \& Energy Society General Meeting, Colorado, 26-30 July 2015.

Pletka, R., Khangura, J., Rawlins, A., Waldren, E., Wilson, D., “Capital Costs for Transmission and Substations: Updated Recommendations for WECC Transmission Expansion Planning", Western Elect. Coordinating Council, Black and Veatch Project, Overland Park, KS, USA, Tech. Rep. Project 181374, 2014.

Pudney, D., 2012, "A Review of HVDC in China", Energize, Vol.54, pp. 31-4.

Raza, A., Shakeel, A., Tahzeeb, H., Hassan, M., 2017, “Economic Analysis for HVDC Transmission System in Pakistan", International Journal of Control and Automation, Vol.10, No.11, pp. 29-38.

Rudervall, R., Charpentier, J. P., Sharma, R., "High Voltage Direct Current (HVDC) Transmission Systems Technology Review Paper", Presented at Energy Week 2000, Washington, D.C, USA, 1-17, 7-8 March 2000.

Shuai, J., 2012, Placing of VSC-HVDC Lines in a Meshed AC-Network, Master Thesis, Swiss Federal Institute of Technology, Zürich, Switzerland.

Sood, VK., 2004, HVDC and FACTS Controllers: Applications of Static Converters in Power Systems, Boston, USA, Kluwer Academic Publishers.

Stenberg, N., 2013, The Impact of HVDC Innovations on The Power Industry, Master Thesis, Royal Institute of Technology, Stockholm, Sweden.

TEİAŞ, Türkiye Elektrik İletim A.Ş. 2016 Faaliyet Raporu, https://www.teias.gov.tr/tr-TR/faaliyetraporlari Access Date: 15.03.2020.

TEİAŞ, Türkiye Elektrik İletim A.Ş. 2018 Faaliyet Raporu, https://www.teias.gov.tr/tr-TR/faaliyetraporlari Access Date: 15.03.2020.

The Crown Estate, East Coast Transmission Network Technical Feasibility Study (2008), https://archive.uea.ac.uk/ e680/energy/energy_links/transmission/east_coast_transmission_net work_technical_feasibility_study.pdf, Access Date: 25.03.2020.

Tiku, D., 2014, “DC Power Transmission: Mercury-Arc to Thyristor YGDA Valves [History]”, IEEE Power Energy Magazine, Vol.12, No.6, pp. 76-96.

Träff, V., Lennerhag, O., 2013, Modelling of VSC-HVDC for Slow Dynamic Studies, Master Thesis, Chalmers University of Technology, Gothenburg, Sweden.

Ukil, A., 2015, "Theoretical Analysis of Tuned HVAC Line for Low Loss Long Distance Bulk Power Transmission", International Journal of Electrical Power \& Energy Systems, Vol.73, pp. 433-437.

Van Eeckhout, B., Van Hertem, D., Reza, M., Srivastava, K., Belmans, R. 2010. “Economic Comparison of VSC HVDC and HVAC as Transmission System for a 300 MW Offshore Wind Farm", European Transactions on Electrical Power, Vol.20, No.5, pp. 661-671.

Van Hertem, D., Ghandhari, M., 2010, "Multi-terminal VSC HVDC for the European Supergrid: Obstacles", Renewable and Sustainable Energy Reviews, Vol.14, No. 9, pp. 3156-3163.

Vrana, TK., Energi, S., "Review of HVDC Component Ratings: XLPE Cables and VSC Converters", 2016 IEEE International Energy Conference (ENERGYCON), Leuven, Belgium. 4-8 April 2016.

Xiong, J., Guo, J., Liu, Q., "The Application of HVDC Transmission in Shore Power Supply", 2017 
International Conference on Industrial Informatics-Computing Technology, Intelligent Technology, Industrial Information Integration (ICIICII), Wuhan, China, 2-3 December 2017.

Ye, H., Fechner, T., Lei, X., Luo, Y., Zhou, M., Han, Z., Li, D., 2018, "Review on HVDC Cable Terminations", High Voltage, Vol.3, No.2, pp. 79-89.

Yidong, H., Yu, T., 2013, "Reliability Improvement Strategies for HVDC Transmission System", Energy and Power Engineering, Vol.5, No.3B, pp. 52-56.

Zangana, S., Ercelebi, E., 2016, “Enhance Power Quality by HVDC System, Comparison Technique between HVDC and HVAC Transmission Systems", World Academy of Science, Engineering and Technology International Journal of Electrical, Computer, Energetic, Electronic and Communication Engineering, Vol.10, No. 2, pp. 271-279.

Zeng, H., Gao, K., Zhu, Z., Li, D., Yang, R., Yang, L., "Research on Difference between HVDC and HVAC Cable Shielding Materials", 2018 Condition Monitoring and Diagnosis (CMD), IEEE, Perth, Australia, 23-26 September 2018. 